\title{
SPIRITUAL HERITAGE OF N. GASRI IN THE LITERARY AND CULTURAL CONTEXT OF THE EARLY $20^{\mathrm{TH}}$ CENTURY
}

\author{
Tagir Shamsegalievich Gilazov, \\ Kazan Federal University, \\ 18 Kremlyovskaya Str., Kazan, 420008, Russian Federation, \\ tgilazov@bk.ru.
}

\begin{abstract}
The article describes the life and work of Nazip Gasri, who played an important role in the development of literature and culture of the Tatar people at the beginning of the $20^{\text {th }}$ century. The study is based on his articles on literary criticism, history of literature and personalities who ensured the development of education, as well as his individual literary works. N. Gasri's public views, the features of his artistic thinking, the focus of his interests and the range of his works are depicted in the context of literature and culture of the early $20^{\text {th }}$ century. The article highlights the connection between the spiritual heritage of the writer and Arab and Oriental literature.

The article analyzes and systematizes information and facts from various sources and attempts to recreate the scientific biography of N. Gasri. For the first time, the articles and memoirs of N. Gasri have become the object of scientific evaluation. Our research is based on the comparative-historical, typological and hermeneutic methods, and the rules and principles of the School of Culture and History.
\end{abstract}

Key words: national renewal, literary ties, cultural-historical school, social opinion, Tatar literature, literary criticism, history of literature.

\section{Introduction}

At the beginning of the $20^{\text {th }}$ century, Tatar literature of the Renaissance was characterized not only by a variety of general concepts, teachings, and philosophical diversity, but also by its own characteristic features of artistic thinking, by the multitude of writers who differed in their creative ways. "As follows from the list, compiled by the literary textual critic Rashat Gaynanov, the total number of poets, prose writers, playwrights, translators, publicists, critics, and children's writers who wrote and were published at the beginning of the $20^{\text {th }}$ century reached 800 (this figure is also approximate - Z. R.)" [Rəmiev, 2004, p. 4], - writes Z. Ramiev. Despite the fact that at that time scientific works about G. Tukay, G. Iskhaki, F. Amirkhan, G. Ibragimov, Derdemend, G. Kamal, Sh. Kamal were regularly published, determining the mainstream of the verbal art development, the names and works of a number of writers were still in the shadows. The inclusion of their spiritual heritage into scientific research and the task of familiarizing the modern reader with their works is one of the crucial problems facing literary scholars.

It is gratifying that the desire to eradicate "white spots" in our spiritual heritage has not only survived, but also made some progress in this area in the late $20^{\text {th }}-$ early $21^{\text {st }}$ centuries. The publications are as broad thematically as they are formally diverse. For example, let's name R. Mardanov, who collected both the names and works of the writers whose works were published in periodicals, in particular on the pages of "Shura"[Mardanov, 2001]; F. Dzhavkharova, who studied the literature of the Astrakhan region [Жәүkhərova, 2003]; R. Musabekova's monographic research, thoroughly investigating the life and creative path of S. Sunchalay, one of the representatives of this generation [Musabekova, 2001]; R. Biktashev's monographic research [Biktashev, 2007], dedicated to Akhmetzhan Biktimirov. In addition, this can include the works by little-known or completely unknown writers, published in collections of works of various literary genres ([Tatar shigriiate: XX gasyr bashy, 2004], [Tatar khikəialəre, 2007], [Epik shigriiat: XX йөz bashy, 2002], [Gilyazev, 2008], [Mirasybyzny tuplau iulynda..., 2010], books about the heritage of individual writers ([Gasri, N. Ismail Bek Gasprinsky, 2004], ["Uilasam ui..., 2005], [Sunchələi, 2005], [Sengati, 2007]). In his book "Tatar Poetry: The Beginning of the $20^{\text {th }}$ Century", Z. Ramiev, in particular, writes that the number of those who worked in the field of poetry in this literary-historical period exceeded three hundred; he briefly describes the lives and publications of 81 less known poets, 
more fully revealing their creative achievements [Tatar shigriiate: XX gasyr bashy, 2004]. Such literary critics and textual critics as F. Ibragimova, Z. Ramiev, Z. Mukhametshin, R. Mardanov, and F. Yakhin took great pains to return these writers' works to the people.

Raised on the work of the outstanding Tatar educators of the turn of the $19^{\text {th }}$ and $20^{\text {th }}$ centuries: Sh. Mardzhani, Kh. Faezkhanov, N. Khalfin and K. Nasyri - and inspired by the democratic changes of the First Russian Revolution, the Tatar youth did not only get a school education and study in Russia, but also went to higher educational institutions abroad developing the national perception of the world. G. Rakhim, G. Gubaidullin, N. Khalfin, Sh. Mukhammedyarov, G. Karam, and M. Kaibyshev were among them. So was N. Gasri. He studied at the literary department of Istanbul University in Turkey and represented the "second generation" of those who came onto the literary scene in the 1910s. N. Gasri graduated from secular schools, gymnasiums and higher educational institutions, thus he did not experience any madrasah education limitations. The article aims to interpret the spiritual heritage of $\mathrm{N}$. Gasri in the literary and cultural context of the $20^{\text {th }}$ century. An attempt is made to collect facts related to his life and to recreate his scientific biography. It is for the first time that a group of articles and literary works of N. Gasri has been introduced into literary circulation. The critic's scientific and theoretical views contributed to the formation of a scientific concept for the study of Tatar literature, the solution of theoretical problems in criticism, the enrichment of Tatar literature with new forms and descriptive techniques for the artistic embodiment of human life. The qualities, highlighted above, determine the scientific novelty and relevance of the topic chosen for this work.

\section{Materials and methods}

This research is based on N. Gasri's scientific and critical articles, publicistic works and literary works, closely related to current problems and literary-aesthetic ideas of Tatar literature and culture of the early $20^{\text {th }}$ century. To this end, we used the cultural-historical, comparative-historical, and biographical methods. The main tenet of the cultural-historical school on the connection of literature, national traditions and the historical process underlies the study of the writer's spiritual heritage and the literary progress and culture of the early $20^{\text {th }}$ century.
A comprehensive study of N. Gasri's spiritual heritage in the context of Arab and Eastern culture has led to the use of the comparative method, which made it possible to identify the structural components of Tatar socio-philosophical, scientific, literary, and historical ideas of the early $20^{\text {th }}$ century. In addition, the principle of historicity was used, which enabled us to study the literary phenomena from the point of view of their origin, development, and historical ties.

\section{Main part}

N. Gasri was a prominent critic, publicist, writer, and journalist of the early 1930s.

There are no works that specifically study the lifestyle and literary-scientific activity of N. Gasri. However, in recent years, T. Gilazov has studied the works of the critic, dedicated to the outstanding figures of the Tatar people, the issues of criticism and literature [Gilazov, 2008], [Gilazov, 2012], [Gilazov, 2016], [Gilazov, 2017]. The literary critic D. Zagidullina's work "Modernism and Tatar Prose of the Early 20 $0^{\text {th }}$ Century" [Zagidullina, 2003] is dedicated to new literary phenomena and research in the art of words in the context of new concepts and philosophical teachings of the early $20^{\text {th }}$ century [Zagidullina, 2003], the artistic qualities and the philosophical aspects in the content of N. Gasri's literary works.

Owing to his reputation of a "literary critic and a talented journalist" among the Tatar intellectuals, certain facts about N. Gasri were recorded in various sources and memoirs. They help restore critical moments in his life as a critic and a writer. Nazip Gasri (Maulambirdiev Muhammadnazip Allabirde uly) was born into the family of a spiritual leader in the Kazi village of the Astrakhan volost in 1886. Many sources mention that $\mathrm{N}$. Gasri studied at the gymnasium in Astrakhan. The monograph by F. Dzhaukharova, who studied Tatar culture, literature, and the history of public opinion in this region on a conceptual basis, clarifies some moments in N. Gasri's life. The author also notes N. Gasri when speaking about the state and development of the educational system in that region, when the "Darel-Adep" school closed on January 27, 1910, as a result of the nationalcolonial policy of the Russian Empire [Dzhaukharova, p. 40]. This Jadid school was opened in 1906, and during these years N. Gasri's pedagogical activity obviously began. F. Dzhaukharova mentions the publication of $\mathrm{N}$. Gasri's poems, along with the publications of Vakif Jalal, Kashshaf Patiya, Kalimulla Sagdi, 
Zarif Bashiri, Sagit Sunchalay, Gabdulla bin Mustakayev, Mohammadhadi Timergalin, and Badretdin Kilachi in the Astrakhan periodicals, [Жәүkhərova, p. 105]. G. Iskhaki's article "The Artist Gabdulla Kari" (1936) writes about N. Gasri's studies at the literary faculty of Istanbul University: "He (N. Gasri - T. G. notes) was a young man who loved literature and theater, understood beauty, and who graduated from the literary faculty of Istanbul University" [Iskhaki, 2011, vol. 11, p. 105]. According to some facts, it is assumed that N. Gasri, when in exile in the city of Pinega, the Arkhangelsk province, escaped from there and lived in Istanbul from May 1908 to the autumn of 1909 and from the autumn of 1910 to the end of 1911. The acquaintance of the writer with N. Gasri was most likely to take place at that time. It is also likely that their creative friendship began precisely during these years. Although the year of publication is unclear, researchers clearly indicate N. Gasri as the author of the Turkiclanguage book "Gayaz Iskhaki from Northern Turkish Writers" (See: [Iskhaki, 2006, vol. 6, p. 421], [Iskhaki, 2001, vol. 8, p. 419]). N. Gasri spent the spring of 1913 in Astrakhan. This is evidenced by the publication" of a letter of condolences in the city newspaper "Volga" on the occasion of G. Tukay's death and a telegram of condolence from Astrakhan to the newspaper "Koyash" [Tukai - iadkərlərdə, pp. 761, 879].

In the autumn of 1913, N. Gasri began working as a teacher of Tatar literature in the Khusainiya madrasah in Orenburg. According to $M$. Rakhimkulova, who depicted the history of the school from different angles, in addition to teaching the history of Tatar literature, N. Gasri also headed the primary department of the madrasah [Rakhimkulova, p. 13, 33-34]. In the issue of "Il", the newspaper dated November 14, 1913, he published the article "Our Literature Needs Criticism" under the pseudonym "Nazip Gasri, a teacher of literature in the Khusainiya madrasah" [Gilazov, 2008, p. 241]. From 1912 to 1915, the writer and literary critic M. Gali studied at the Khusainiya madrasah in Orenburg. In his memoirs, he wrote that he became involved "in writing on the advice of Nazip Gasri, their literature teacher (1886-1937)" [See: Our writers: a biobibliographic reference, p. 323]. This means that when M. Gali studied at the madrasah, N. Gasri taught there. This information is highlighted in the "Literary Dictionary", compiled by I. Rami and supplemented by R. Dautov during the years of perestroika [Rəmi, Dautov, p. 74].
But there is one fact that requires to be clarified. Some sources indicate that in 1913-1915, N. Gasri worked as the editor of the newspaper "Il", published in Petrograd and Moscow [Tatar Encyclopedia, 2010, vol. 2, p. 536], [Rami, Dautov, p. 105]. G. Iskhaki also mentioned his journalistic activities in the "Il" in 1915: "It was the beginning of 1915. Once Gabdulla Kari came to our office. ... At that time, Nazip Gasri worked as a secretary in the administration of the "Il" newspaper" [Iskhaki, 2011, vol. 11, p. 294]. There is no doubt that N. Gasri occupied the position of a secretary at the "Il". As we know, the hectic life of the 1910s, which made him constantly move from place to place, and ruthless service undermined $\mathrm{G}$. Iskhaki's health, and in late April - early May, 1914, on the advice of doctors, he went to Finland for sanatorium treatment [Iskhaki, 2006, vol. 6, p. 436]. This means that when G. Iskhaki was not in Moscow, certain issues of the newspaper were published under N. Gasri's editorship.

The October Revolution of 1917 changed the life of dozens Tatar intellectuals, including the life of N. Gasri. His biography of the 1920s and 1930s contains many blank spots and undisclosed facts. There are many reasons for this. First, in our opinion, N. Gasri was having a hard time because of G. Iskhaki's emigration, who was his spiritual support, as well as F. Tuktarov and G. Teregulov, who were constantly in touch with him. Secondly, it took time to determine his social and spiritual ideological position on a new social and cultural environment. After the October Revolution, he returned to his native land and lived in his native village for 3 years. In 1920, he got married. We cannot tell for sure what N. Gasri was doing at that time. However, Khamit Gumerov's memoirs "Fatih Amirkhan in Astrakhan", published in R. Amirkhanov's book "Memories of Fatih Amirkhan", shed light on this issue. According to the information available there, F. Amirkhan traveled to Astrakhan in June 1925. He stayed at the house of the city mullah, publisher and editor of the "Idel" newspaper Gabdrakhman Gumeri. While talking about G. Gumeri's literary and scientific activities, about the culture of the region, $\mathrm{F}$. Amirkhan asked him about N. Gasri. "In short, N. Gasri had been removed from public affairs since 1918, he lived near the city in the village of Kazavyl with his family and was engaged in gardening and selling his products," he said. "He delivered produce not only from his own garden, but also from other gardens, and even from other villages, going up the Volga (to Nizhniy Novgorod 
- Kh. G. notes) all summer and selling a lot there", he said. Both of them were saddened by the fact that N. Gasri moved away from cultural, educational and publishing affairs" [Fatikh Amirkhanov turynda istaleklar, p. 131].

When life improved a little, N. Gasri, like his contemporaries M. Galau, F. Agiev and others, moved to Moscow in search of asylum. After 1925, he worked in higher educational institutions of Uzbekistan. He became one of the victims of a horrific campaign of repression. Weakened $\mathrm{N}$. Gasri died in prison during interrogation in 1937. According to various sources his death occurred in different years. In his book "Memories of Fatih Amirkhan" (2005) in "Notes and Comments" R. Amirkhanov indicates the year of 1934 [Amirkhanov, p. 218]. Although we turned to the state archives of the Orenburg region and the archives of Moscow to clarify some facts, related to N. Gasri, this has not yielded any results yet. This means that it is necessary to continue research in this area in the future. It seems that the Tatar scientists and writers have not systematized the facts and information about N. Gasri's life and work.

According to the data, during the First Russian Revolution, N. Gasri began his literary activities, testing the power of his pen in various fields and quickly became an outstanding journalist, critic, publicist, writer, and teacher. $\mathrm{He}$ published voluminous monographic theoretical articles, literary portraits, reviews, articles signed "Nazip Gasri”, "N. Gasri ”, "Nazip Gasri, a teacher of literature in the Khusainiya madrasah" in such newspapers and journals as "Borhane tarakkyi" (1906-1910), "Khamiyat" (1907- 1908), "Mizan" (1908 - 1909), "Idel" (1907- 1914), "Yoldyz" (1906-1917), "Il" (1913-1915), "Suz" (19151916), "Beznen il" (1916-1917), "Saray" (19171918), “An” (1912-1918).

In 1910, the critic received recognition, his work got more intensive. In the article "The Progress of Our Press and Literature (instead of the annual report)", G. Ibragimov, while analyzing the 1913 mass media and books, noted that new signatures had appeared in periodicals. Along with J. Validi, M. Hanafi, “... it would undoubtedly be a mistake not to include in the lists Mr. Nazip Gasri, who was remembered for his criticism of one work and several feuilletons in the "Il"'" [Ibragimov, p. 201] - he wrote. In his article "Our Literary Criticism", G. Sagdi pointed out G. Ibragimov, J. Validi, G. Rakhim, Kh. Iskandarov, Kh. Karimov and N. Gasri among the critics who appeared in the field of literary criticism in 1910. [Sagdi , 1927, p. $18]$.

The formation of the history of literature as a science, a branch of Tatar literary education, dates back to the first quarter of the $20^{\text {th }}$ century. The periodicals of the 1910s published articles by R. Fakhretdinov, F. Karimi, J. Validi, F. Amirkhan, G. Iskhaki, G. Ibragimov, Kh. Karimov, and N. Gasri, which covered the development of Tatar literature from the past to the present day and the tendency to evaluate it by highlighting the changing trends in the literary process and new literary phenomena.

In the $4^{\text {th }}$ issue of the journal "Sovremennik" in 1911, Nazip Gasri's voluminous article "Awakening of the Russian Tatars and Their Literature" was published, reflecting the qualitative changes in the literature of the Renaissance. Tatar G. Iskhaki and the outstanding Russian writer A. Gorky became friends. They exchanged letters from 1911 to 1923. A. Gorky asked Gayaz Iskhaki to write about the trends in Tatar literature, its main characteristics, and prominent representatives for the journal "Sovremennik". Iskhaki's life during those years was especially tense and difficult. Although in one of the letters he promised: "I will send an essay on the state of Tatar literature in the near future" [Iskhaki, 2013, p. 11], due to certain circumstances he could not keep his word. He entrusted this work to his colleague $\mathrm{N}$. Gasri. The article in Tatar was translated into Russian by G. Sverdlov and published in the journal.

Educated in Turkey, influenced by European culture and literature, N. Gasri examined the history of national literature in the context of the socio-political situation in Russia, the historical events and the changes that they brought to the Tatar world. The introductory part of the voluminous article described the tragic history of the Tatar people and the development of social and spiritual thought in detail. The author defined the stages of socio-political changes: the Tatars' active participation in trade and agriculture, the restoration of cultural ties with Central Asia and Turkestan, and reforms of Catherine II [Nedzhib, 1911, pp. 166-179].

Assessing the revival in the social life and economic activity of the Tatar people, N. Gasri analyzed the qualitative changes in cultural and literary life. At the beginning of the $19^{\text {th }}$ century, the first Tatar printing house was opened in Kazan. $\mathrm{N}$. Gasri connected the revolution in Islam with the activities of the educator, theologian, historian, and 
philosopher Shigabetdin Mardzhani. The founder of the New Tatar literature, Kayum Nasyri, came to the fore. One of the important trends of Kayum Nasyri's multifaceted activity was his selfless service aimed to liberate the Tatar press from the monopoly of Turkestan mysticism and the Tatar language from the influence of foreign languages [Nedzhib, 1911, p. 170]. The critic associated the quality of the Tatar literature revival with the awakening of public opinion among the Tatars, caused by the religious reforms of Sh. Mardzhani.

In 1883, in Bakhchysarai, Ismagil Gasprinsky began to publish the first Tatar newspaper "Tarjeman" ("The Translator"). The critic compared the amazing role that this intellectual played in the social and spiritual revival of the Tatar people with the spring messenger - the swallow. From the very first issue of his newspaper, Gasprinsky called the Tatar people to Europeanize, speaking about the need to make changes in madrasah and criticizing the old teaching methods. He highly appreciated the activities of Zakir Bigiev, Riza kazy Fakhretdinov and Fatih Karimi, who depicted national reality in realistic details in their works, showing the role of literary and journalistic publications of the late $19^{\text {th }}$ century in updating Tatar literature in terms of content and form.

N. Gasri emphasized that when Tatar literature was at a crossroads, a new era in the history of Tatar literature began with the works of Gayaz Iskhaki. "When Tatar literature was at a crossroads, in 1897, Gayaz Iskhaki entered the literary arena. With his appearance, Tatar literature began a new stage, a sharp turn in the development of realism" [Nedzhib, 1911, p. 173]. In addition to literary issues, the critic paid attention to the issues of the Tatar language, and singled out Gayaz Iskhaki as the founder of Tatar literature and "the father of the Tatar literary language". Among those who came to poetry during the First Russian Revolution, he noted two people - Gabdulla Tukay and Sagit Ramiev. In the poetry of 1905-1910, he highlighted realistic poetry, which was imbued with the desires and aspirations of the people and strove for a more complete picture of Tatar life, romantic, evoking lyrical and personal experiences, and rich in poetic ornaments.

In 1910, expanding the boundaries of the national framework, the question of raising the level of Tatar literary criticism was on the agenda, aimed at assessing the art of the word, striving for the European level, and determining the stages of its development. In this regard, his article "Our
Literature Needs Hypocrisy" (1913) was published. N. Gasri shared his views on the role of literary criticism in the development of literature, on the prestige of the critic, referring to the symbols of the garden, water and light, which had very rich and distinctive traditions of conventionally romantic use in the world and Turkic-Tatar literature [Gasri, Odəbiiatybyz...]. The author considered criticism as "one of the most important areas in the development of literature" and "offered the principle of objectivity in literary criticism in evaluating works of fiction" [Mukhamadiev, p. 16].

N. Gasri published outstanding works of writers who played a decisive role in the revival of Tatar literature, or articles evaluating their work as a whole. In the genre of a creative portrait, his article "Gayaz Iskhaki from the Northern Turkish Writers" was published. The critic's literary and aesthetic views, his attitude to literature and art were shaped under the influence of his colleague G. Iskhaki. Relying on the basic rules of the School of Culture and History, he defined the role of the art of words as the service to the nation and the contribution to its development "...the editor's goal in writing a work is to provide meaning, not to 'demonstrate art" [Iskhaki, 2001, 8 vol., p. 164].

$\mathrm{N}$. Gasri wrote that the genre required authors should synthesize ideological and aesthetic features of their work with important events in life. The author of the article divided Iskhaki's current literary activity into two periods: the first was "nationalism", the second was "humanism". He named the main works of each period and analyzed them in detail. He called the story "Ike yoz eldan son inkyiraz" ("The Crisis Two Hundred Years Later") the most outstanding work of the first creative period. G. Iskhaki's role in the history of Russian speech art was highly appreciated as that of the "strong founder of young Tatar literature and the greatest literary figure". N. Gasri noted the realistic style and folk spirit of G. Iskhaki's work and the social and national character of his themes.

Five-six years after the publication of $\mathrm{G}$. Ibragimov's story "Yashlar khayatennan ber laukha" ("Plague from the Life of Youth"), critical articles by S. Ramiev and J. Validi were published in periodicals. In the newspaper "Il", N. Gasri published a review of G. Ibragimov's work "Yashlar khayatennan ber laukha" [Gasri, Iashlar khaiatennan ber laukha, 1914]. Analyzing the problematics of the work, the author gave a brief overview of the spiritual movement of the Tatar 
youth in the $19^{\text {th }}$ and $20^{\text {th }}$ centuries, highlighting the stages in the development of "philosophy", "nationalism" and "humanity".

Having described the history of the Tatar youth movement at the turn of the century, the author assessed the image of Salim, who personified this movement. He emphasized that the events, described in the story, did not show the changes in the spirit and masculinity of the protagonist, that his intellectual transitions were not reflected in Salim's actions. The fact that Salim, whom the writer called a "ghost", changed every three or four years, showed that his character lacked stability [Gasri, Iashlar khaiatennan ber laukha 1914].

The spiritual heritage of N. Gasri includes his publications devoted to national poetry, its essence, general state and the trends of development, as well as his works on individual representatives of Tatar poetry. One of them is an article-review of $Z$. Burnasheva's book of poems "Gyiffat tutash shigyrlare" ("The Poems of the Girl Gyiffat"), published in the issues of the "Il" newspaper on March 4 and 11, 1915. This was the first voluminous work of the Tatar press, dedicated to the work of the poetess, in which Z. Burnasheva was first mentioned.

In the introductory part of the article, N. Gasri shared his views on contemporary poetry, its essence, its difference from other forms of art, such as music, painting, sculpture, as well as on the development trends of national poetry. When the critic expressed his thoughts about the profession of a writer, about poetic abilities and talent, he fell into the line with the school of "spiritualists" founded by G. Ibragimov, the school which said these qualities were inborn, given by nature, that this was divine power; at the same time, it was necessary to develop and strengthen them [Gasri , Gyiffat tutashnyң shigyrlare, 1915].

In terms of these scientific insights, the author of the publication proceeded to analyze the creativity of the girl Gyiffat. N. Gasri defined the collections of Z. Burnasheva's poems in the poetic horizon of 1914 as "melodic dear stars", and called the author a poetess of emotions in Tatar poetry, a "poetess of feelings". The emphasis was on personal, individual emotional experiences of the poetess. Thus, the reasons for the feelings, experienced by the girl Giffatt who came to poetry, determined the ideological content of her works.

In his article-review, N. Gasri raised the issue of literary influence, interliterary ties, the question of intertextuality, which entered the scientific circulation in the middle of the $20^{\text {th }}$ century, and $\mathrm{N}$.
Gasri considered this scientific problem, based on the poems by the poetess Gyiffat and the poet G. Tukay, an outstanding classic of Tatar literature. The critic noted that the poet's work had a great impact on the lyrical poetry of the girl Gyiffat. G. Sagdi, who studied the influence of Tukay's work on the ideological and aesthetic characteristics and linguistic style of poetry, confirmed that $\mathrm{Z}$. Burnasheva was Tukay's student [Sagdi, 1923, p. 6]. Z. Burnasheva was a poetess brought up under the influence of Tukay, she was from the "Tukay poetry school". Between the lyrics of Gyiffat and the works of G. Tukay, there was a strong innerspiritual and external connection. The poetess did not separate her poetry, her creative experience from the great Tukay; on the contrary, she proudly wrote about the favorable influence the poet's work exerted on her poems and positioned herself as a follower of Tukay's traditions.

In the last part of the article, N. Gasri explored the aesthetic nature of the poetess's works and their ideological and aesthetic properties. $\mathrm{He}$ concluded that Gyiffat was a representative of romantic poetry, based on the fact that the poet's poems reflected her soul and emotions. Her poetry was characterized by imagery, the beauty of language and style, lightness, and grace. He was sincerely glad that a new type of romanticism would be raised to new heights thanks to a woman's heart in Tatar literature.

In the critical heritage of N. Gasri, there are also publications evaluating the literary works of this period. His voluminous review "Hisametdin Menla. A Literary Analysis" (Works of Musa Akegetzade), dedicated to the prominent novel of the writer-educator M. Akyeget, appeared in the journal "An" in the combined issues 9-10, 23-24 of 1915. The critic wrote that M. Akyeget's novel marked the beginning, the first sign of contemporary art, based on the author's scientific views on the literary process and the patterns of the literary development. This opinion was supported by the outstanding literary critic G. Ibragimov, who singled out the epochs of Tatar literature with more than a thousand years' history. The scholar emphasized that the era of the Jadids, which followed the era of Kadims, began with $\mathrm{M}$. Akyeget's novel "Hisametdin Menla": "The second is Jadid literature: this era began with "Hisametdin Menla", published 30 years ago [Ibragimov, 1978, p. 290].

N. Gasri defined the role of Tatar literature as the one serving its nation and its cultural development in accordance with the rules of the 
School of Culture and History: "We cannot look at poems or literature through the eyes of art; we begin to use literature, to receive material benefits from it. "Hisametdin Menla", the first page of our new literature, is an example of this "[Gasri, Hisametdin Menla, 1915, p. 192].

N. Gasri noted that this work, which was a model of new literature, was influenced by the ideological, spiritual, and formative aspects of the "old literature". According to the author, medieval literature was closely related to the literature of the East and "South Ottoman literature". N. Gasri gave a brief overview of the history of both literatures, highlighting the stages of their development, the tendencies of changes, their outstanding writers and works with embodied thematic motifs, linguistic features, and images.

After the historical excursion, N. Gasri went on to evaluate "Hisametdin Menla" noting that it raised social and national problems that were urgent for that time. He wrote that the autor's national feelings were stronger than those of $\mathrm{Z}$. Bigiev and R. Fakhretdinov, he explained this by referring to certain facts from Akyeget's life: "On the one hand, "Tarjeman" contributed to the development of his national feelings, on the other hand, his education in the Russian school, or its ineffectiveness during Akyeget's study had its negative influence" [Gasri, Hisametdin menla, 1915 , p. 193]. He pointed out that in a literary work the problem of individual freedom was at the core [Tatar odəbiiaty ... p. 293, 1985]. This was shown through the worldview and actions of the main characters of the novel, Hanif and Hisametdin Menla. According to the reviewer, the most important quality in a person's life was one's personal freedom: "One valuable and good thing in a person's life is freedom: we can defend our freedom" [Gasri, Hisametdin Menla, 1915, p. 419 ,]. The problem of personal freedom was intertwined in national reality with the problems of women's status, freedom of marriage, and women's education. The author of the article wrote that Khanifa fought for her happiness, in contrast to the idealized Salima from "Salima yaki gyiffat" ("Salima or the Mother of God") by R. Fakhretdinov, and put her on a par with Galia, the main character of G. Iskhaki's drama "Aldymbirdem" (1907).

Further, the author of the article characterized Hisametdin Menla. He returned from Turkey to teach children in his home in a new way, and soon found support in the fathers of children who learned to read and write. In addition, he was a wealthy and professional young man who was engaged in agriculture [Gasri, Hisametdin Menla, 1915, p. 193]. The critic emphasized that $M$. Akyegetzade described his heroes in a certain ideal light, based on the principles of enlightenment realism. The writer considered high morality to be the most important quality of his characters.

N. Gasri introduced Mullah Bikbulat, the negative characters of the novel, who ensured the development of the novel's events, and Bek Gali Javatov, the richest man in the village. When analyzing the character of Mullah Bikbulat, the critic used the term "type" as he was a generalized kind of the old-fashioned, ancient, immoral "type" of that period [Gasri, 1915, Hisametdin Menla, p. 416]. The review highlighted the main conflict between Bikbulat Menla and Hisametdin Menla on the issue of teaching methods and teaching efficiency. It emphasized that the central conflict was constantly aggravated by auxiliary contradictions.

N. Gasri considered Abuzar bey, Hisametdin Menla and Hanifa in the novel "Hisametdin Menla" to be prototypes and images of nationalists and national leaders who belonged to the group of contemporary Tatar intellectuals. When F. Amirkhan's drama "Tigezsezler" ("Unequal") (1914) was published, there followed the scandalous article "Yaltyravykly yalgan" ("The Shining Lie") by F. Saifi-Kazanly (1916), denying the possibility of formation of Rukia-type people in Tatar reality. Kh. Iskanderov, who saw eye to eye with N. Gasri, noted that in Tatar life, Rukia, Kamila and Fatima could be found on the path of spiritual rebirth, and even proved their existence in the Tatar world (See: [Gilazov, 2008, p. 92-93]).

$\mathrm{N}$. Gasri also evaluated the artistic features of M. Akyeget's works, supporting M. Akagegt's intentional use of letters. The letters performed the mission of revealing the emotions, characters, views and attitudes of the main characters. Also, letters served to enhance pure divine love and the feeling of being in love. The novel described in real detail the inhabitants of the village, their way of life, other ethnographic features, wedding ceremonies, and national customs. The reviewer noted the role of emotional monologues in revealing the inner world and psychological experiences of the main character Hanifa: the prewedding mood of Hanifa, who was forcibly married off, and her feelings conveyed through a monologue. The depiction of nature, in addition to specifying the time and place of events, fulfilled 
the ideological and aesthetic task of revealing the psychology of the characters.

$\mathrm{N}$. Gasri sought to find his place in the socialist society, which began to take shape after the October Revolution of 1917. He evaluated literary and scientific works according to new requirements for literature and art in terms of new social and cultural traditions. The newspaper "Eshche", dated January 20, 1926, published the review of G. Nigmati's monograph "Adabiyat maydanynda" ("In the Field of Literature") (1925). The critic noted the value of the book, summarizing the achievements of Tatar literature, which grew under the influence of Arab culture from the 1880s to the present day, and arranging them into a certain system. He wrote that the researcher, relying on the services of foreign and Russian scholars, gave a typological description of the techniques of realism, romanticism, symbolism, imagination and futurism and, on the basis of this, analyzed the works of the Tatar classics and young writers. The reviewer examined the features of G. Nigmati's literary activities, the methodology of studying literary works, showing his comprehensive and systematic approach to literary phenomena.

According to the critic, G. Nigmati interpreted fiction in relation to other types of art, fine arts, songs, and music. It is from this point of view that E. Nigmatullin assessed the originality of the methodology used to evaluate N. Gasri's scientific works: "The writer Nazip Gasri emphasizes and supports generalization, theoretical significance of the book and the author's desire to explore literary works in connection with aesthetics and other forms of art, such as music and fine arts" [Galimdzhan Nigmati ..., p. 222]. According to his observations, the author of the article came to the conclusion that not only Tatar fiction, but also music and fine arts would take a worthy place in the "Palace of Fine Arts of Arab Industry".

Tatar literature, having mastered the trends of realism and romanticism, which depict life and reality, the spirit and desires of the creator, begins to explore new ways of knowing the world and understanding the essence of life. Creative people study philosophical teachings, scientific concepts, literary, and aesthetic systems. In order to embody a new spiritual content, to make the art of speech more elegant and influential, they turn to modernist techniques and means of representation, formed in European and Russian cultures. Along with G. Ibragimov, F. Amirkhan, S. Ramiev, Derdemend, Sh. Kamal, G. Rakhim, G. Gubaidullin, M.
Kaibyshev and others, who received their literary education in secular schools, a new wave of authors joined Tatar literature. N. Gasri was among them.

N. Gasri's work "Gyishkym kharabalare" ("Ruins of Love") (1916) was written in a synthesis of aesthetic achievements and traditions of oriental and Arabic verbal art. The fact that Iskander, whom Gulnar had loved since childhood, fell in love with Leila, made her endure hardships and loneliness. Her morbid mood was described against the backdrop of autumn landscape with yellow leaves falling from trees. The images of autumn, spring, winter, gardens, and leaves were widely used in Tatar literature and served to convey a philosophical meaning, "... the autumn garden reminded of death, loss of hope, faith in love, and happiness" [Zagidullina, 2007, p. 11] ... Possessing a strong position, the symbol of ruins in the title of the work refers to rejected love, to the loss of the desire to live. The work contains a philosophical thought that there is only one beloved, and true love cannot get over betrayal. In the story, the theme of love and beauty of lovers is spiritualized and shown in the synthesis of Eastern and Arab cultures.

Joining the art studies of that period and the experiments carried out along this path, N. Gasri wrote his work "Mazarstanda" ("In Mazarstan") (1916), discussing the problems of life and death, mortality and eternity, which cannot be comprehended by reason. One of the beautiful autumn days, the narrator leaves home to visit the grave of his beloved Lamigan, whose cause of death is unknown. He continues on his way to where a girl's voice, breaking the mysterious silence in the cemetery, is heard, it sounds like the Koran readings. He walks by the grave of a longdead old man, a woman who was stabbed to death by her alcoholic husband, a girl who caused her death by falling in love with two guys, and a young man who committed suicide. Finally, he weeps at Lamigan's grave, remembering past happy days. In the young man's heartfelt monologue, we hear a hymn to the love and beauty of his young beloved Lamigan. Further, the author is deified in the image of a lover through religious and mystical phenomena that cannot be consciously perceived: "young, beautiful leaves of the tomb keeper's sycamore begin to pray," and the "shining white light rises above the maiden's grave". After a while, the mysterious narrator comes to his senses and calmly goes back. 
Near the grave whose stone is overgrown with moss due to its age, the voice of an old man reciting an ayah can be heard from under the stone, suddenly everything changes and the Day of Judgment begins. The dead rise to the ground, "an old man with a large white beard and white eyebrows covering his eyes sits on a stone," reciting the sura; a young man who committed suicide out of love comes out from under the gravestone and sits down on it with his head resting on his hands, etc. Various sounds and noises are heard from all sides.

Published in Moscow in 1931, G. Sagdi's monograph "Symbolism of the Turnd" ("On Symbolism") has not lost its relevance today. It assesses this work as an example of symbolism written "under the influence of Russian literature". "Nazip Gasri's lyrical story of "Mazarstanda "(“An", no. 5, 1916) was a powerful work that exemplifies this. This was the most characteristic work on this way" [Sagdi, 1931, pp. 113- 114]. The scholar noted that the author's stories with such content were created under the influence of "The Sounds from the Grave" by Halit Zia, the famous author of Ottoman verbal art influenced by French decadent literature.

The hidden content of the story, written in symbolism, was expressed through symbolic images: "Oh magical, mysterious life! I live! - you say and stand on the sand; it slides under your feet and runs away!" framed by a sentence rich in emotionally sounding conventional images. It serves to express the existential view that human life and its desires are false, illusory. Among the dead resurrected from tombs on the Day of Judgment, there are those who took the lives of others or committed suicide in violation of religious law and religious teachings. N. Gasri also confirmed the religious idea that those who committed great sins before the God were not happy in that world and that they failed to find peace here. The literary critic F. Bashirov also drew attention to the symbolism of images and words, the philosophical and existential content of the work [Bashirov, p. 248].

N. Gasri's story "Songyr khan tubasenda" ("On the Roof of Songyr Khan"), in which his socio-philosophical ideas were skillfully embodied with reference to national history, was published in the 2nd issue of the journal "An" in 1916. The boy, who grew up on the stories of his grandmother about Khan Songyr from an early age, created the image of the Khan in his dreams when he became an adult student. When the horse of the Muslim
Khan Songyr grew old, he built a palace of hazel with a door covered with silver. The merciful and compassionate khan treated the poor and needy in his palace, and when the poor were fed and drunk, they were given a cup of kumis and some money. The people thanked the khan and prayed for his health. In his palace, the khan kept scholars, monks of that time, Gali Hazrat, Said Battal Gazi, singers who played the dumra and poets of the palace. When the khan died of old age, he was brought from the city to the cemetery, sprinkled with silver coins on the ground and buried on the red roof.

Khan Songyr is a symbol that can be attributed to different concepts. D. Zaghidullina associated it with the concept of a "prophet" who "preserved the nation, statehood, and today the authors assign to this ideal the mission of awakening and reviving the nation" [Zagidullina, 2003, p. 59]. Its meaning can also be interpreted in the sense of the idea of a just ruler, embodied in medieval Tatar literature, the teachings of the "perfect man" and "shepherds", which meant prophets and scientists in Muslim culture. At the end of the work, the reader imagined that "the image of Khan Songyr with tired and drooping eyebrows came to life, his heart was filled with national feeling and historical memory was awakened: 'What unknown historical, nationalistic dream surrounds me, extending my imagination to the vastness, glory of Tatar history: Khans, times of Khans ..." [Gasri, Songyr tubasenda, 1916, p. 33]. This enhances the social and nationalist significance of the symbol. In this story, N. Gasri embodied the problem of creating "spiritual leaders", goblins, personalities and writers, what he himself was, who served to save the Tatar nation during a crisis.

N. Gasri also contributed to the development of Tatar journalism, which followed the path of the independent development during the period of Iskhaki and Tukay at the beginning of the $20^{\text {th }}$ century. Unlike his contemporaries-publicists, he considered the important role of individuals in the course of history in contrast to the postulate that, according to Marxism, the social development was ensured by the class struggle. Therefore, some of his most influential publicistic works were the ones about the Tatar people in a period of dramatic historical and social changes, "forces that help history, accelerate the work that history will do slowly" [Validi, p. 119]. The beginning of a series of this type articles was laid by the publication "Tukaev Died" in the "Idel" newspaper on April 5, 1913 in connection with the untimely death of the national poet G. Tukay, who made qualitative 
changes in Tatar literature and brought it to the world arena. Written in a beautiful, refined language, typical of the Marcia genre, it exalts Tukay. It was written because of the loss of the great poet and is imbued with a feeling of sorrow and that is why it is close to the genre of an obituary [Gilazov, 2008, p. 175].

N. Gasri's respect for G. Tukai was formed under the influence of his spiritual leader $\mathrm{G}$. Iskhaki, the founder of Tatar realistic literature. This is followed by the author's comment. He sees the death of the poet in the obituary as a result of the narrow Tatar environment, the negative impact of national reality on him, the indifference of the Tatar nation towards the great poet.

After the death of Ismail bey Gasprinsky, a Tatar intellectual, enlightener who made great efforts to develop and renew the culture and education of the Turkic peoples, F. Amirkhan, G. Iskhaky, G. Battal, M. Bigiev, G. Bubi, J. Maksudi, S. Maksudi, and others published their articles. N. Gasri's obituary "Altyn torek egyldy" ("The Golden Turk Fell") on the death of Ismail Gasprinsky was published in the "Il" newspaper on September 25, 1914. The article was permeated with a sense of sadness. The author of the article called Ismail Gasprinsky, who devoted all his efforts to renewing national education, awakening national self-awareness in the heart of every Turkic-Tatar heart, to the development of Tatar periodicals and the press, the idea of "unity of thought, word and deed", and the cultural development of Turkic peoples in Russia, "golden Turk".

N. Gasri's article "Shihab khazrat" was published in the issue of "Il" newspaper dated January 2, 1915 on the occasion of the 100th anniversary Shigabutdin Mardzhani's birth and 25th anniversary of his death. In this article, written in the genre of a jubilee article, the publicist seeks to determine the place of Sh. Mardzhani in the history of the culture of the Tatar people and the value of his scientific activities. N. Gasri explains the appearance of such a great person as Sh. Mardzhani in the context of his time and environment [Gasri, Shihab khazrat, 1915]. Although the number of such great figures could be counted on the fingers of one hand, he expresses regret that the Tatar people failed to appreciate them highly enough.

N. Gasri singled out the main directions of Sh. Mardzhani's diversified activities. Firstly, he assessed the great theologian of his time as a religious reformer; secondly, he singled out the activities of Sh. Mardzhani in the field of research and writing of national history and calls him a "national historian". The author's views on Sh. Mardzhani were consonant with the assessments of J. Validi, F. Amirkhan, G. Iskhaki, G. Tukay, and others.

The content of N. Gasri's article "Madrasah Problem" (1914), on the one hand, was consonant with the problems of journalism by G. Iskhaki, F. Amirkhan, G. Tukai, G. Ibragimov, and G. Kamal; on the other hand, it correlated with the theme of the role of individuals, leaders in the life of the people. The article is devoted to the problem of training mullahs in madrassas, the lack of universities for the Tatars, the problem of training teachers and raising public figures. According to the publicist, the responsibilities of mullahs changed over time. He looked at the modern mullah from different angles: he was a theologian, an educated adviser to the people on life issues, and a public figure familiar with national issues. To achieve these goals, it was necessary to modernize and reform the education system in madrasahs.

N. Gasri examined the issue of training "spiritual leaders" in the national-social context and within the multicultural space. From the point of view of the formation of skills and knowledge and the traits of character required for the highquality work of a mullah, who was a spiritual figure, he devised the structure and amount of education in the first madrasah in terms of developing certain skills and providing knowledge. It was argued that in order to be informed in accordance with the laws of the Koran and Sharia and teach religious sciences, fulfilling the duties of a purebred national servant, one should study the national language, spelling, Tatar literature and historical sciences. Due to the fact that a Muslim cleric was a citizen of Russia, his knowledge of the history of the Motherland was also a condition. To serve as "the shepherd of one spirit, the leader of the community," a mullah must have knowledge of general history, psychology, and social sciences.

The article "Ismagyil bek Gasprinsky va gomumi adabi tel" ("Ismail bey Gasprinsky and the Common Literary Language") (1914) broadens the horizons of N. Gasri's scientific views. It is included in the book "Ismagyil bek Gaspraly", written by F. Gaffarova on the occasion of the 90th anniversary of Ismail Gasprinsky's death [Isməgyil bek Gasprinski, 2004]. Evaluating the newspaper "Tarjeman", which was published by Ismail bek, N. Gasri, who lived with the idea of uniting all 
Turkic peoples, presented his views on the language, its essence and the features of its development in his article. He saw language as the foundation of the nation, part of its culture that sustained and preserved it. He defined the value of Ismail bey's work in establishing a "common literary language" for the Turkish-Tatar nation.

Based on the laws of the development of the Turkic languages, he distinguished three languages: "The language and literature of the Tatars of the Volga region, the Caucasian dialect and literature, the language of the southern Turks". The history of the formation of these languages, their main features, determined the development of literature, and the place and prospects of a common literary language. Among them was the language of the Volga Tatars, which had emerged over the past thirty years and had united under one banner the languages of the Bashkir, Misharsk, Nogai, and Siberian Tatars, which had created excellent literatures.

\section{Results}

1. N. Gasri is a bright representative of the second generation of Tatar writers who were educated in the literary schools of G. Iskhaki, G. Tukay, F. Amirkhan, and G. Ibragimov, under the influence of the system of socio-philosophical views of the Tatar educators Sh. Mardzhani, K. Nasyri, and I. Gasprinsky.

2. N. Gassri was going through a busy and difficult life. Having received his education in secular educational institutions of various levels in Russia and Turkey, he became a theoretically prepared, creative, and multifaceted person and devoted himself to serving the Tatar people.

3. He actively worked in the field of Tatar literary criticism, literary history, and Tatar journalism, making a significant contribution to the social, spiritual, and cultural revival of the Tatar people at the beginning of the $20^{\text {th }}$ century. His work was closely related to the Tatar verbal art, which had embarked on the "path of accelerated development", and the national culture, which faced Europeanization while preserving its national features.

4. N. Gasri conducted his scientific research in the context of social progress, the history of the Tatar people; he also evaluated literature, art, and outstanding personalities in terms of serving their people and the benefit of the nation.

\section{Conclusion}

Thus, Nazip Gasri, along with the classics and talented researchers of Tatar literature, played an important role in the spiritual and cultural upsurge of the Tatar people at the beginning of the $20^{\text {th }}$ century. He was one of the descendants of $20^{\text {th }}$ century Tatar intellectuals who were broad and talented personalities and awakened in their hearts a desire to serve the social and cultural revival of their native people. In terms of literary, aesthetic, and world outlook, N. Gasri was close to G. Iskhaki, the leader of the social and national liberation movement. The poet's scientific and journalistic work was based on the tenets of the School of Culture and History, and the principles of historicity and nationalism.

\section{References}

Amirkhanov, R. (2005). Fatikh Amirkhanov turynda istaleklar [Memories of Fatih Amirkhan]. 255 p. Kazan, Tatar kit. nashr. (In Tatar)

Bashirov, F. (2002). XX yoz bashy Tatar prozasy [Tatar Prose of the Early $20^{\text {th }}$ century]. 287 p. Kazan, Fiker. (In Tatar)

Biktashev, R. I. (2007). Literaturnoe $i$ publististicheskoe nasledie Akhmetzyana Biktimirova (nachalo 20 veka): avtoref. diss kand. filolog. nauk [Literary and Journalistic Heritage of Akhmetzyan Biktimirov (the early $20^{\text {th }}$ century): Ph.D. Thesis Abstract]. Kazan, 31 p. (In Russian)

Ediplarebez: biobibliografic beleshmalek (2009) [Our Writers: A Biobibliographic Reference].T. 1, төz. R. N. Dautov, R. F. Rakhmani. 751 p. Kazan, Tatar kit. nashr. (In Tatar)

Epik shigriiat: XX üez bashy (2002) [Epic Poetry]. Төз. F. Z. Iakhin. 463 p. Kazan, izd."Khater" (TaRIKH). (In Tatar)

Fəizi, M. (2007). Әsarlar [Works]. Tez. həm keresh məkalə avt. T. Sh. Gilazov]. 295 p. Kazan, Magarif. (In Tatar)

Galimdzhan Nigməti: tormyshy, iazmyshy, fənnimetodik eshchənlege (2018) [Galimdzhan Nigmati: Life, Destiny, Scientific-Methodical Activity]. T. Sh. Gyilaжev redaktsiiasendə. 252 p. Kazan, "Brig" nashriiaty. (In Tatar)

Gasri, N. (2004). Ismagil bek Gasprinskiy ham gomumi adabi tel [Ismagil Bey Gasprinsky and the Common Literary Language]. Ismagil bek Gasprinsky. Pp. 60-64. Kazan, Alma-Lit. (In Tatar)

Gasri, N. (2008). Әdabiiatymyz monəkykyidka токhтаж [Our Literature Needs Critics]. Retsenzialərdən təgziialərgə: XX йөz bashy Tatar ədəbi tənkyite. Pp. 238-241. Kazan, Tatar. kit.nəshr. (In Tatar)

Gasryi Nazhip (2010) [Gasri Nazip]. Tatar entsiklopediase: 6 tomda. Bash mekhərrire M. Kh. Khəsənov, жavaply mekhərrir G. S. Sabirkanov. Kazan 
"TR FAneң Tatar entsiklopediase instituty" dəylət ucherezhdeniiase. 2 t: G - Y. p. 80. (In Tatar)

Gasri, N. (1913). Tukaev vafat [Tukaev Died]. Idel. April 5. (In Tatar)

Gasri, N. (1914). Iashlar khaiatennan ber laukha [Plague from the Life of Youth]. Il. Gyinvar 2 (No. 10). (In Tatar)

Gasri, N. (2001). Shimali torki adiplarennan Gayaz Iskhaki. Osorlar 15 tomda [Gayaz Iskhaki from Northern Turkish Writers. Works in 15 volumes].T. 8: Gaiaz Iskhakyinyн tormyshy həm іжаty turynda zamandashlary (1898-1917) [tez., tekst həm aңlat. əzerl., keresh syz avt. F. Ibraimova]. Kazan, Tatar kit. nashr. Pp. 154-164. (In Tatar)

Gasri, N. (1915). Gyiffat tutashnył shigyrlare [Poems of the Girl Gyiffat]. Il. Mart 5 (No. 81); Mart 11 (No. 84). (In Tatar)

Gasri, N. (1915). "Hisametdin menla" (Akegetzada asare) Ber tahlil adabi [Hisametdin Menla. A Literary Analysis]. Аң. No. 9, pp. 189-194; No. 23-24, pp. 416424. (In Tatar)

Gasri, N. (1926). Әdəbiiat məidanynda [In Literature Square]. (Məskəүdə USSR halyklarynyн Yzyk nəshriyaty nəshere, matur basmada, 110 bitlek. Iptəsh Galimkan Nigməti əsəre). Eshche. Gyinvar 20 (No. 749). (In Tatar)

Gasri, N. (1914). Madrasa masalase (syezd dik' 'katena) [Madrasah Problems]. Il. Iiun' 17 (No. 31). (In Tatar)

Gasri, N. (1916). "Songyr khan tubase"nda [On the Roof of Songyr Khan]. Аң. No. 2, pp. 29-33. (In Tatar)

Gasri, N. (1916). Mazarstanda [In Mazarstan]. Аң. No. 5, pp. 78-82. (In Tatar)

Gasri, N. (1916). Gyishkym kharabalare [Ruins of Love]. Аң. No. 7, pp. 114-118. (In Tatar)

Gilazov, T. Sh. (2017). Rasskaz G. Ibragimova "Odin episod iz zhizni molodezhi" v literaturnoy kritike 1910 godov [G. Ibragimov's Story "One Episode from the Life of Young People" in Literary Criticism of the 1910s]. Filologiia I kultura. Philology and Culture. No. 2 (48), pp. 153-157. (In Russian)

Gilazov, T. Sh. (2016). Adabiiat belemenen ber tarmagy bularak adabi tankyit [Literary Criticism as a Part of Literary Theory]. Tatar ədəbiiaty tarikhy: sigez tomda. $4 \mathrm{t}$.: XX yez bashy. Tez. R. F. Rahmani; fən. mekh. R. K. Ganiev. Pp. 428-453. Kazan, Tatar kit. nashr. (In Tatar)

Gilazov, T. Sh. (2008). Retsenziyalardan tagziialarga: XX yoz bashy Tatar adabi tankyite [From Reviews to Condolences: Tatar Literary Criticism in the Beginning of the $20^{\text {th }}$ Century]. 254 p. Kazan, Tatar kit. nashr. (In Tatar)

Gilazov, T. Sh. (2012). Nazhip Gasryinyy adəbitankyidi eshchanlegendo Z. Burnasheva (Gyiffat tutash) shigriiate [Z. Burnasheva's (Gyiffat Tutash) Poetry in Nazip Gasri's Literary Criticism]. Fənni iazmalar 2012: KFU пуң Philology həm səngat' institutynyн fənni iazmalary / Fən. mөkh. R. R.Жamaletdinov. Pp. 84-91. Kazan, Kazan university, (In Tatar)
Gilazov, T. Sh. (2016). Nəж⿻ір Gasryi [Nazip Gasry]. Gabdulla Tukay Entsiklopediase, bash mөh. Z. Z. Rəmiev. P. 195. Kazan, G. Ibraimov isem. Tel, ədəbiiat həm səngat' instituty. (In Tatar)

Jamal Validi: adabi ham tarikhi-dokumental жcyentyk (2010) [Literary and Historical-Documentary Collection]. Tez. Dilərə Abdullina, Жәүdət Minnullin. 624 p. Kazan, Жyen. (In Tatar)

Жәүkhərova, F. Kh. (2003). Osterkhan tobagendə tatar adabiyaty (XIX-XX yoz bashy) [Tatar Literature of the Astrakhan Region (the $19^{\text {th }}$-the beginning of $20^{\text {th }}$ century)]. 127 p. Kazan, Magarif. (In Tatar)

Iakhin, F. $X X$ ŭez bashy Tatar epic shigriyate (2002) [Tatar Epic Poetry of the Early $20^{\text {th }}$ Century]. Epic shigriiat: XX йөz bashy. Tөz. F. Z. Iakhin. Pp. 516. Kazan, izd. "Khater" (TaRIKH). (In Tatar)

Ibragimov, G. (1978). Osarlar 8 tomda: Tom 5: adabiat haм sangat' turynda makalalar khezmatlar (1910-1933) [Works in 8 Volumes: Vol. 5.: Articles, Works on Literature and Arts (1910-1933)]. Tez., text., isk. həm aңl. əzerl. Khəsənov M. Kh., Gainanov R. R. 615 p. Kazan, Tatar kit. nashr. (In Tatar)

Ibragimov, G. (2019). Matbugat vo adabiyatymyznył baryshy (ellyk khisap urynyna) [The Progress of Our Press and Literature (in place of the annual report)].

Osərlər: ədəbiiat həm səngat' turynda məkalələr, hezmətlər (1910-1917). Tөz., tekst., isk. həm аңl. әzerl. Z. G. Mehəmmətshin; fən. mekh. T. Sh. Gyilaжev. Pp. 192-202. Kazan, Tatar kit. nashr. (In Tatar)

Iskhaki, G. (2005). Gaiaz Iskhakyinyp tatar adabiiaty turyndagy doklady [G. Iskhaki's Report on Tatar Literature]. Osərlər: 15 tomda. $6 \mathrm{t}$.: Publitsistika həm ədəbi tənkyit məkalələre. Tөz. Z. Rəmiev, F. Ibrahimova; tekst. əzerl. F. Ibragimova; aңl. həm isk. əzerl. Z. Rəmiev; fən. mөkh. F. Musin]. Pp. 190-203. Kazan, Tatar kit. nashr. (In Tatar)

Iskhaki, G. (2005). Osarlar: 15 tomda. T. 6: Publitsistika ham adabi tankyit' makalalore (19021914) [Works: In 15 Vol. Vol. 6: Journalism and Articles on Literary Criticism (1902-1914)]. Tez. Z. Rəmiev, F. Ibrahimova; aңl. həm isk. əzerl. Z. Rəmiev; fən. mekh. F. Musin. 447 p. Kazan, Tatar kit. nashr. (In Tatar)

Iskhaki, G. (2001). Osarlar 15 tomda.T. 8: Gaiaz Iskhakyinyu tormyshy hom ixçaty turynda zamandashlary (1898-1917) [Works: In 15 Vol. Contemporaries about Gayaz Iskhaki's Life and Work]. Tөz., tekst həm aңlat. əzerl., keresh syz avt. F. Ibragimova. 447 p. Kazan, Tatar kit. nashr. (In Tatar)

Iskhaki, G. (2011). Osarlar 15 tomda. T. 11: Publitsistika (1934-1936) [Works: In 15 Vol. Vol. 6: Journalism(1934-1936)]. Tomny tez., tekst.,isk. həm aңlat. əzerl .; keresh məkalə avt. Z. Møhəmmətshin; fən. mekh. Z. Rəmiev. 399 p. Kazan, Tatar kit. nashr. (In Tatar)

Iskhaki, G. (2013). Maksim Gorkiiga (1911, Gyinvar 6) [To Maksim Gorki (1911, January 6)]. Osərlər 15 tomda. T. 14: khatlar həm avtobiografik iazmalar (1902-1954) [tomny tөz., tekst həm aңl. əzerl., 
keresh syz avt. F. Fəizullina. 11 p. Kazan, Tatar kit. nashr. (In Tatar)

Iskhaki, G. (2014). Osərlor: 15tomda : Gaiaz Iskhakyinyp̧ tormyshy həm iæçaty turynda istaləklar həm makalalar (1923-1990) [Works in 15 Vol.. Vol. 15: Memories and Articles about Gayaz Iskhaki's Life and Work]. Tomny tez., tekst., isk. həm həm aylat. əzerl. G. Hannanova, R. Kadyrov. 527 p. Kazan, Tatar kit. nashr. (In Tatar)

Khəsəvnekh, A. Ә. (2010). Il. Tatar entsiklopediase: 6 tomda [Il. Tatar Encyclopedia: In 6 Volumes]. Bash mohərrire M. Kh. Khəsənov, жavaply mehərrir G. S. Sabirжanov. Vol. 2: G-Й. 536 p. Kazan, "TR FAneң Tatar entsiklopediase instituty". (In Tatar)

Mordanov, R. (2001). "Shura" zhurnaly (19081917): adabiyat mokalalor [Journal "Shura": Literary Issues]. 152 p. Kazan, Rukhiiat. (In Tatar)

Mirasybyzny tuplau iulynda (2010) [On the Way to Collecting our Heritage]. XX йөz bashy tatar balalar ədəbiyatynnan. Tez. F. Ibragimova. 200 p. Kazan, "Iman" nashr. (In Tatar)

Musabekova, R. R. (2001). Sagit Sunchelei: sud'ba i tvorchestvo [Sagit Sunchalay: His Fate and Work]. 157 p. Kazan, "Unysh". (In Russian)

Mukhamadiev, R. S. (1982). Problemy formirovaniia tatarskoi literaturnoi kritiki (1905-1917) [Problems of Tatar Literary Criticism Formation]. Kazan, Tatar kit. nashr. 144 p. (In Russian)

Nedzhib, (Gasri N.) (1914). Probuzhdenie russkikh tatar $i$ ikh literatura [Awakening of the Russian Tatars and Their Literature]. Sovremennik. No. 10, pp. 166177. (In Russian)

Rakhimkulova, M. (1997). Medrese "Khusainiia” v Orenburge [Madrasah "Khusainiya" in Orenburg]. 251 p. Orenburg. (In Russian)

Rəmi, I. G., Dautov, R. N. (2001). Әdabi syzlek [Literary Dictionary]. (Elekke chor tatar ədəbiyate həm mədəniiate buencha kyskacha beleshməlek). 399 p. Kazan, Tatar kit. nashr. (In Tatar)

Rəmiev, Z. Z. (2004). Keresh [Introduction]. Tatar shigriiate: XX gasyr bashy [Tatar Poetry: The Beginning of $20^{\text {th }}$ Century]. Pp. 3-8. Kazan, Magarif. (In Tatar)
Rəkhmati, S. (1915). Gyiffat tutash maktybe monasabate ila [Gyiffat Tutash and School]. Ioldyz. October 2. (In Tatar)

Səgdi, G. (1923). Tatar shagyilore arasynda Tukai [Tukay among Tatar Poets]. Beznen iul. No. 8- 9, pp. 2- 7, p. 6 (In Tatar)

Səgdi, G. (1927). Bezda adabi tənkyit' [Our Literary Criticism]. Kazan, Beznen iul. 22 p. (In Tatar)

Səgdi, G. (1932). Simvolism turynda [About Symbolism]. 135 p. (99 p.) Moscow, Tsentrizdat. (In Tatar)

Sengati, G. (2007). Shigrlar hom prosa [Poetry and Prose]. 184 p. Kazan, "Meddok" nashr. (In Tatar)

Sunchələi, S. (2005). Osarlar ham khatlar [Works and Letters]. Tөz., tekst.,isk. həm aңl. əzerl. Z. Rəmiev. 367 p. Kazan, Tatar kit. nashr. (In Tatar)

Tatar adabiyaty tarikhy (1984) [History of Tatar Literature]. In 6 vol. Vol. 1. Urta gasyrlar dəvere. 567 p. Kazan, Tatar kit. nashr. (In Tatar)

Tatar khikaialare (2007) [Tatar Sroties]. Kitapny tөz., tekst. əzerl. həm keresh məkalə avt. D. F. Zagidullina. 399 p. Kazan, Magarif. (In Tatar)

Tatar shigriiate: XX gasyr bashy (2004) [Tatar Poetry: The $20^{\text {th }}$ Century]. 447 p. Kazan, Magarif. (In Tatar)

Tukai - iadkarlarda (2015) [Tukay in Memoirs]. 2 tomda.T. 1: Isəleklər, məkalələr, təgziyalər, telegrammalar. Tezychelər: R. F. Islamov, filologiia fənnəre doktory, Ж. S. Miңnullin, tarikh fənnəre kandidaty. 968 p. Kazan, Жyen. (In Tatar)

“Uilasam ui, syzlyi ky̧̧lem, syzlyi жçan...” (2005) ["When I think about it, my heart aches, my soul aches ... "New Facts about Sagit Ramiev's Life and Work]. Səgyt Rəmievneң tormysh iuly həm іжаtyna karata іаңа məglymatlar. Tez.-avt. Ch. Zaripova-Chetin; fən meh. A. Saiapova. 203 p. Kazan, "Yanalif" publishing house. (In Tatar)

Zagidullina, D. F. (2003). Modernizm ham XX üөz bashy tatar prozasy [Modernism and Tatar Prose of the Beginning of $20^{\text {th }}$ Century]. 255 p. Kazan, Tatar kit. nashr. (In Tatar)

\title{
ХХ ГАСЫР БАШЫ ӘДӘБИ ҺӘМ МӘДӘНИ КОНТЕКСТЫНДА Н. ГАСРЫЙ РУХИ МИРАСЫ
}

\author{
Таһир Шәмсегали улы Гыйлажев, \\ Казан федераль университеты, \\ Россия, 420008, Казан ш., Кремль ур., 18 нче йорт, \\ tgilazov@bk.ru.
}

\begin{abstract}
Мәкаләдә XX гасыр башында татар халкының әдәбияты һәм мәдәнияте күтәрелешендә зур роль уйнаган Нәжип Гасрыйның тормыш юлы һәм рухи эшчәнлеге тикшерелә. Аның әдәби тәнкыйтькә, әдәбият тарихына караган мәкаләләре, милли мәдәният һәм мәгариф үсешен тәэмин иткән шәхесләргә багышланган язмалары фәнни тикшеренүнең объекты булып тора. Н. Гасрыйның ижтимагый карашлары, сәнгатьчә фикерләвенең хосусиятләре, ижат кыйбласы һәм
\end{abstract}


даирәсе XX гасыр башы әдәби һәм мәдәни контекстында шәрехләнә. Шулай ук әдип рухи мирасының Гареб һәм Шәрык әдәбиятлары белән бәйләнешләренә дә игътибар ителә.

Төрле чыганакларда һәм язмалардагы мәгълүматлар һәм фактлар барлана һәм, алар бер системага салынып, Н. Гасрыйның фәнни биографиясен тудыру омтылышы ясала. Бәяләү объектына нисбәтле Н. Гасрыйның аерым мәкаләләре, истәлек-хатирәләре беренче тапкыр фәнни әйләнешкә кертелә. Фәнни эзләнүләрдә чагыштырма-тарихи, типологик һәм герменевтика методларына, культура-тарих мәктәбе кагыйдәләре һәм принципларына таяныла.

Төп төшенчәләр: милли яңарыш, әдәби бәйләнешләр, культура-тарих мәктәбе, ижтимагый фикер, татар әдәбияты, әдәби тәнкыйть, әдәбият тарихы.

\section{Кереш}

XX гасыр башы Яңарыш чоры татар әдәбияты гыйльми концепцияләр, тәгълиматлар һәм фәлсәфи төрлелектән тыш, сәнгатьчә фикерләү хосусиятләре, ижатка килү юллары белән бер-берсеннән аерылып торган каләм ияләренең күплеге белән дә характерлана. "Егерменче гасыр башында ижат итеп, матбугатта чыгыш ясаган шагыйрь, прозаик, драматург, тәржемәче, публицист, тәнкыйтьче hәм балалар язучыларының гомуми саны, әдәбиятчы-текстолог Рәшат Гайнанов төзегән исемлектән (кульязма. - acc. 3.P.) күренгәнчә, сигез йөзгә житә (бу сан да якынча. - асc. 3.P.)", [Рәмиев, 2004, б. 4], - дип яза 3. Рәмиев. Бу вакытта сүз сәнгатенең магистраль үсеш юлын билгеләгән Г. Тукай, Г. Исхакый, Ф. Әмирхан, Г. Ибраһимов, Дәрдемәнд, Г. Камал, Ш. Камалларны шәрехләгән фәнни хезмәтләр даими басылып торса да, дистәләгән каләм ияләренең исемнәре һәм ижатлары күләгәдә кала килә. Аларның рухи мирасын фәнни әйләнешкә кертү, ижат жимешләре белән бүгенге укучыны таныштыру әдәбиятчы галимнәр алдында торган жаваплы бурычларның берсе булып тора.

Шунысы куанычлы: рухи мирасыбыздагы “ак таплар”ны бетеру теләге сүздә генә калмады, XX гасыр ахырында - XXI гасыр башларында бу юнәлештә билгеле бер уңышларга ирешелде. Басмалар шәкли яктан төрле булган кебек, тематик яктан да киңкырлы. Мәсәлән, вакытлы матбугатта, аерым алганда “Шура” сәхифәләрендә язышкан ижат әһелләренең исемнәрен һәм әсәрләрен барлап кына калмыйча, гомуми сыйфатларын да бәяләгән Р. Мәрданов [Мәрданов, 2001], Әстерхан төбәге әдәбиятын өйрәнгән Ф. Жәүһәрова [Жәүһәрова, 2003]; бу буын аерым вәкилләре - С. Сүнчәләйнең тормыш һәм ижат юллары жентекле тикшерелгән Р. Мусабекова [Мусабекова, 2001], Әхмәтжан Биктимеровка багышланган Р. Бикташевның [Бикташев, 2007] монографик эзләнүләре шундыйлардан.
Моннан тыш исемнәре аз яисә бөтенләй билгеле булмаган әдипләрнең әсәрләре әдәби төр, жанрлар билгесе буенча тупланып нәшер ителгән жыентыклар ([Татар шигърияте: XX гасыр башы, 2004], [Татар хикәяләре, 2007], [Эпик шигърият: XX йөз башы, 2002], [Гыйлажев, 2008], [Мирасыбызны туплау юлында..., 2010], бу чор аерым вәкилләренең киңкырлы мирасларына багышланган китаплар ([Исмәгыйль бәк Гаспринский, 2004], [Уйласам уй..., 2005], [Сүнчәләй Сәгыйть, 2005], [Сөнгати, 2007]) шулар жөмләсенә керә. Аерым алганда, 3. Рәмиев “Татар шигърияте: XX гасыр башы” китабында әлеге әдәби-тарихи чор шигърият мәйданында эш иткәннәр санының өч йөздән артуын күрсәтә; икенче дәрәжәдәге сиксән бер шагыйрьнең тормыш юлы хакында кыскача мәгълүмат һәм аларның ижат йөзен тулырак ачкан басмаларын урнаштыра [Татар шигърияте: XX гасыр башы, 2004]. Бу катлам каләм ияләренең әдәби жәүһәрләрен халыкка кайтаруда Ф. Ибраһимова, 3. Рәмиев, 3. Мөхәмммәтшин, Р. Мәрданов, Ф. Яхин кебек әдәбиятчы галимнәр-текстологлар зур көч куялар.

XIX-XX гасыр чикләрендә Ш. Мәржани, X. Фәезханов, Н. Хәлфин, К. Насыйри кебек күренекле татар мәгърифәтчеләре әзерләгән туфрактан дым алган татар яшьләре, Беренче рус инкыйлабының демократик үзгәрешләре белән рухланып, мәктәп-мәдрәсә белеме белән генә чикләнмичә, Россиядә генә түгел, чит илләрдәге югары уку йортларында укып һәм тәрбияләнеп, милли чынбарлыкны төрле юнәлештә үстерү һәм камилләштерү эшенә керешәләр, әлеге хәрәкәткә кушылып китәләр. Г. Рәхим, Г. Гобәйдуллин, Н. Хәлфин, Ш. Мөхәммәдьяров, Г. Кәрам, М. Кайбышев шундыйлардан. Алар арасында Төркиянең Истанбул университетының әдәбият бүлегендә белем алган Н. Гасрый да бар. Ул 1910 елларда, мәдрәсә белеме белән чикләнмичә, дөньяви уку йортларын, гимназияләрне, югары мәктәпләрне бетереп, әдәбият мәйданына килгән “икенче” 
буын вәкиле булып тора. Мәкаләдә $\mathrm{H}$. Гасрыйның рухи мирасын XX гасыр әдәби һәм мәдәни контекстында шәрехләү максаты куела. Аның тормыш юлына караган фактлар тупланып, әдипнең фәнни биографиясен тудыру омтылышы ясала. Н. Гасрыйның бер төркем мәкаләләре һәм әдәби әсәрләре беренче тапкыр фәнни әйләнешкә кертелә. Тәнкыйтьченең гыйльми нәзари фикерләре татар әдәбиятын өйрәнүнең гыйльми концепциясен формалаштыруга, тәнкыйтьнең теоретик проблемаларын хәл итүгә, татар әдәбиятын кеше яшәешен сәнгатьчә гәүдәләндерүнең яңа формалары, тасвирый алымнары белән баетуга үзеннән өлеш кертә. Югарыда ассызыкланган сыйфатлар хезмәт темасының фәнни яңалыгын һәм актуальлеген билгели.

\section{Фәнни хезмәтнең материалы һәм методлары}

Хезмәттә Н. Гасрыйның XX гасыр башы татар әдәбиятының һәм мәдәниятенең актуаль проблемалары hәм әдәби-эстетик фикерләре белән тыгыз бәйләнгән гыйльми-тәнкыйди мәкаләләре, публицистик язмалары һәм әдәби әсәрләре фәнни тикшеренү эшенең материалы булып тора. Куелган максатка ирешү өчен, культура-тарих, чагыштырма-тарихи, биографик методларга мөрәжәгать ителде. Культура-тарих мәктәбенең әдәбиятның милли традицияләр һәм тарихи процесс белән бәйләнеше хакындагы төп кануны тәнкыйтьче həм әдипнең рухи мирасын XX гасыр башы әдәби барышы hәм мәдәнияте белән тыгыз бәйләнештә карарга мөмкинлек бирде.

Н. Гасрыйның рухи мирасын Гареб һәм Көнчыгыш мәдәнияте контекстында комплекслы өйрәнү XX гасыр башы татар ижтимагый-фәлсәфи, гыйльми, әдәби-тарихи фикерләренең структур компонентларын аерып чыгарырга ярдәм иткән компаративистикачагыштырмалы методны файдалануга этәрде. Болардан башка әдәби күренешне аның барлыкка килү, үсеше һәм тарихи бәйләнешләр ноктасыннан өйрәнүгә юл ачкан тарихилык принцибы да кулланылды.

\section{Төп өлеш}

H. Гасрый - XX гасыр беренче утызъеллыгының күренекле тәнкыйтьчесе, публицисты, язучысы һәм журналисты.

Н. Гасрыйның тормыш юлын һәм әдәбигыйльми эшчәнлеген махсус өйрәнгән хезмәтләр юк. Шулай да соңгы елларда Т. Гыйлажев гыйльми-тәнкыйди

эшчәнлегендә тәнкыйтьченең татар халкының күренекле шәхесләренә, тәнкыйть һәм әдәбият мәсьәләләренә багышланган язмалары өйрәнелде [Гыйлажев, 2008], [Гыйлажев, 2012], [Гыйлажев, 2016], [Гыйлажев, 2017]. Әдәбият галиме Д. Заһидуллинаның XX гасыр башы сүз сәнгатендәге яңа әдәби күренешләрне, эзләнүләрне яңа концепцияләр, фәлсәфи тәгълиматлар контекстында тикшергән "Модернизм һәм XX йөз башы татар прозасы" [Заһидуллина, 2003] хезмәтендә Н. Гасрый әдәби әсәрләренең сәнгати сыйфатлары, ә эчтәлегенең фәлсәфи катламы бәяләнә.

Татар зыялылары даирәсендә “әдәби тәнкыйтьче һәм талантлы журналист" буларак билгеле булу сәбәпле, аның хакында аерым фактлар төрле чыганакларда, истәлекхатирәләрдә теркәлеп калган. Алар тәнкыйтьче hәм язучының тормыш юлының аерым чорларын торгызырга ярдәм итә. Нәжип Гасрый (Мәүләмбирдиев Мөхәммәтнәжип Аллабирде улы) 1886 елда Әстерхан волосте Казы авылында рухани гаиләсендә дөньяга килә. Күп чыганакларда Н. Гасрыйның Әстерхандагы гимназиядә белем алуы искәртелә. Шушы төбәктәге татар мәдәниятен, әдәбиятын һәм ижтимагый фикер тарихын концептуаль нигездә тикшергән Ф. Жәүһәрованың монографик хезмәтендә $\mathrm{H}$. Гасрыйның тормыш юлындагы аерым мәсьәләләргә ачыклык кертелә. Төбәктәге мәгариф хәле һәм аның үсеше турында сүз алып барганда, ул Россия империясенең милликолониаль сәясәте нәтижәсендә 1910 елның 27 гыйнварында ябылган “Дарел-әдәп” мәктәбенең мөгаллимнәре арасында $\mathrm{H}$. Гасрыйны да саный [Жәүһәрова, б. 40]. Димәк, бу жәдиди мәктәпнең 1906 елда ачылуын искә алсак, Н. Гасрыйның педагогик эшчәнлеге шушы елларда башлануы ачыклана. $\Phi$. Жәүһәрова Әстерхан шәһәрендә нәшер ителгән вакытлы матбугат битләрендә Вакыйф Жәләл, Кәшшаф Патии, Кәлимулла Сәгъди, Зариф Бәшири, Сәгыйть Сүнчәләй, Габдулла бине Мостакаев, Мөхәммәтһади Тимергалин, Бәдретдин Киләчи белән беррәттән Н. Гасрый шигырьләре дә басылуны билгеләп уза [Жәүһәрова, б. 105]. Г. Исхакыйның “Артист Габдулла Кари” (1936) мәкаләсендә вакыты төгәл күрсәтелмәсә дә, Н. Гасрыйның Истанбул университетының әдәбият факультетында укуы бәян ителә: “Ул (Н. Гасрый. - acc. Т.Г.) әдәбият, театрны бик сөюче, нәфасәтне 
(нәфислекне. - acc. Т.Г.) аңлаучы, Истанбул дарелфөнүненең (университетының. - асс. T.Г.) - әдәбият шөгъбәнен (бүлеген. - асс. Т.Г.) тәмам иткән бер егет иде" [Исхакый, 2011, 11 т., б. 105]. Аерым фактларга караганда, Н. Гасрыйның, гимназия ябылгач, 1910 ел урталарында Төркиягә килүе фаразлана. Билгеле булганча, Г. Исхакый Архангель губернасы Пинега шәһәрендә сөргендә вакытында, аннан качып китеп, 1908 елның жәеннән 1909 елның көзенә, 1910 елның көзеннән 1911 елның ахырларына кадәр Истанбулда тора. Язучының Н. Гасрый белән шушы вакытта очрашуы бик мөмкин. Алар арасында ижади дуслык нәкъ шушы елларда башлана да булса кирәк. Басылып чыгу елы бәхәс уятса да, төрек телендәге “Шимали төрек әдипләреннән Гаяз Исхакый” китабының төзүчесе Н. Гасрый булуы тикшеренүчеләр тарафыннан төгәл күрсәтелә (Кара: [Исхакый, 2006, 6 т., б 421 ], [Исхакый, 2001, 8 т., 419]). 1913 елның яз айларында Н. Гасрый Әстерхан шәһәрендә була. Г. Тукай үлеме мөнәсәбәте белән шәһәрдә нәшер ителгән "Идел" газетасында тәгъзия бастыруы һәм "Кояш" газетасына Әстерханнан кайгы телеграммасы жибәрүе шул хакта сөйли [Тукай - ядкәрләрдә, б. 761, 879].

Н. Гасрый 1913 елның көзендә Оренбургтагы “Хөсәения" мәдрәсәсендә мөгаллим булып эшли башлый, шәкертләргә татар әдәбиятын укыта. Уку йортының тарихын төрле яклап тикшергән М. Рәхимкулова $\mathrm{H}$. Гасрыйның татар әдәбияты тарихын укыту белән бергә, мәдрәсәдәге башлангыч (ибтидаия. - асc.Т.Г.) бүлекләрнең мөдире вазифасын да башкаруын әйтә [Рахимкулова, с. 13, 33-34]. "Ил" газетасының 1913 ел 14 ноябрь санында ул “Мәдрәсәи Хөсәения"дә әдәбият мөгаллиме Нәжип Гасрый” тәхәллүсе белән “Әдәбиятымыз мөнәкъкыйдкә мохтаж” исемле мәкаләсен бастыра [Гыйлажев, 2008, б. 241 ]. Язучы һәм әдәби-гыйльми хезмәткәр М. Гали 1912 елдан 1915 елга кадәр Оренбургтагы "Хөсәения" мәдрәсәсендә белем ала. Ул истәлегендә үзенең “әдәбият мөгаллиме Нәжип Гасрый (1886-1937) киңәше белән язучылык” эшенә тартылуы турында яза [Кара: Әдипләребез: биобиблиографик белешмәлек, б. 323]. Димәк, М. Гали мәдрәсәдә укыган елларда Н. Гасрый да бу уку йортында шәкертләрне укыткан. Бу мәгълүмат И. Рәми төзеп, үзгәртеп кору елларында гына Р. Даутов тарафыннан тулыландырылып нәшер ителгән “Әдәби сүзлек”тә дә ассызыклана [Рәми, Даутов, б. 74].

Әмма өстәмә ачыклык кертүне сорый торган бер факт бар. Аерым чыганакларда 1913-1915 елларда Н. Гасрыйның Петроград hәм Мәскәүдә нәшер ителгән "Ил” газетасында мөхәррир булып эшләве әйтелә [Татар энциклопедиясе, 2010, 2 т., б. 536 ], [Рәми, Даутов, б. 105]. 1915 елда аның “Ил”дә журналистлык эшчәнлеге турында Г. Исхакый да яза: “1915 елның башлары иде. Көннең берендә идарәбезгә Габдулла Кари килеп керде. ... "Ил" идарәсендә ул вакытта кятиб (секретарь, журналист. - acc. Т.Г.) булып Нәжип Гасрый эшли иде" [Исхакый, 2011, 11 т., б. 294]. Н. Гасрыйның “Ил”дә секретарь вазифасын башкаруы бәхәс уятмый. Мәгълүм булганча, 1910 еллардагы тынгысыз тормыш, туктаусыз бер урыннан икенче урынга күченү, ялсыз хезмәт Г. Исхакыйның сәламәтлеген какшата һәм ул, табиблар киңәше белән 1914 елның апрель азаклары - май башларында Финляндиягә барып, санаториядә дәвалана [Исхакый, 2006, 6 т., б. 436]. Димәк, Г. Исхакый Мәскәүдә булмаганда, газетаның аерым саннары Н. Гасрый мөхәррирлегендә нәшер ителгән.

1917 елгы Октябрь революциясе дистәләгән татар зыялыларының тормышын, шул исәптән Н. Гасрыйның да язмышын үзгәртә. Аның 1920-1930 еллар тормыш hәм ижат биографиясендә “ак тап”лар, ачыкланмаган фактлар күбәя. Моның сәбәпләре шактый. Беренчедән, безнең карашыбызча, рухи таянычы булган Г. Исхакыйның һәм аның белән даими аралашып яшәгән Ф. Туктаров, Г. Терегуловларның мөһажирлеккә китүе $\mathrm{H}$. Гасрыйга авыр тәэсир итә. Икенчедән, яңа социаль һәм мәдәни шартларда ижтимагый һәм рухи кыйбланы билгеләү билгеле бер вакыт сорый. Октябрь борылышыннан соң ул, үз ягына кайтып, туган авылында өч ел яши. 1920 елда өйләнә. Бу вакытта Н. Гасрыйның нинди эшчәнлек белән шөгыльләнүе төгәл генә ачык түгел. Шулай да Р. Әмирхановның “Фатих Әмирхан турында истәлекләр” китабындагы Хәмит Гомәровның “Фатих Әмирхан Әстерханда” дигән истәлек-хатирәсендә бу мәсьәләгә беркадәр ачыклык кертелә. Андагы мәгълүматларга караганда, Ф. Әмирхан 1925 елның июнь аенда Әстерханга сәяхәт кыла. Ул шәһәр мулласы, "Идел" газетасының нашире hәм мөхәррире Габдрахман Гомәриләр өендә кунакта була. Г. Гомәринең әдәби-гыйльми 
эшчәнлеге, төбәк мәдәнияте хакында сөйләшеп утырганда, Ф. Әмирхан аннан Н. Гасрый турында сораша. "Кыскасы, Н. Гасрый 1918 елдан бирле жәмәгать эшләреннән аерылган, шәһәрдән ерак түгел Казавыл дигән карьяда (авылда. - acc. Т.Г.) гаиләсе белән яши һәм бакча эше һәм шуның хасыйләтен (нәтижәсен. - acc. Т.Г.) сату белән мәшгуль", - диде. "Үз бакчасыннан гына түгел, бәлки башкаларның, хәтта башка авыллардан да бакча малын алып, жәй буе Идел белән югарыга (Нижний Новгородка - acc. X. Г.) алып барып анда күпләп сатып йөри", - диде. Аның шулай мәдәни, мәгариф яисә матбугат эшләреннән читкә чыгып калуына икесе дә тәэссеф иттеләр (борчылдылар. - acc. Т.Г.)" [Фатих Әмирхан турында истәлекләр, б. 131].

Тормышлар беркадәр жайлангач, $\mathrm{H}$. Гасрый, замандашлары М. Галәү, Ф. Агиев һәм башкалар кебек сыену урыны эзләп, Мәскәү шәһәренә күчә. 1925 елдан соң Үзбәкстан югары уку йортларында эшли. Дәһшәтле репрессия корбаннарының берсе була. Сәламәтлеге зәгыйфьләнгән Н. Гасрый 1937 елда төрмәдә сорау алу вакытында вафат була. Аның үлеме төрле хезмәтләрдә төрле елларга нисбәт ителә. Р. Әмирханов “Фатих Әмирхан турында истәлекләр"(2005) дигән китабындагы “Искәрмәләр һәм аңлатмалар"да 1934 елны күрсәтә [Әмирханов, б. 218]. Н. Гасрыйга караган аерым фактларны төгәлләштеру максаты белән, “Оренбург өлкәсенең дәүләт архивы"на, Мәскәу шәһәре архивларына мөрәжәгать итсәк тә, әлегә нәтижәсе булмады. Димәк, киләчәктә бу юнәлештә эзләнүләрне дәвам итү сорала. Күренә ки, татар галимнәренең һәм язучыларының Н. Гасрый тормыш сукмакларына һәм ижатына караган фактлары һм мәгълүматлары системалаштырылмаган.

Мәгълүматларга караганда, H. Гасрый Беренче рус иникыйлабы елларында әдәби эшчәнлек белән шөгыльләнә башлый, үз каләм көчен төрле өлкәләрдә сынап карый һәм тиз арада күренекле журналист, тәнкыйтьче, публицист, әдип, педагог буларак таныла. Күләмле, тирән фикерле монографик, теоретик мәкаләләр, әдәби портрет, рецензия, рецензиямәкалә жанрындагы язмалар белән "Борһане тәрәккый” (1906-1910), “Хәмият” (1907-1908), "Мизан” (1908 -1909), "Идел” (1907-1914), “Йолдыз” (1906-1917), “Ил” (1913-1915), “Сүз” (1915-1916), “Безнең ил” (1916-1917), “Сарай” (1917-1918), “Аң” (1912-1918) кебек газета- журнал битләрендә "Нәжип Гасрый”, “Н. Гасрый”, “Мәдрәсәи Хөсәения”дә әдәбият мөгаллиме Нәжип Гасрый" имзалары белән чыгыш ясый.

1910 елларда ижаты активлашып киткән тәнкыйтьче танылу ала. Г. Ибраһимов 1913 елгы матбугатка һәм төрле өлкәдә басылып чыккан китапларга анализ ясаган "Матбугат вә әдәбиятымызның барышы (еллык хисап урынына)" дигән язмасында вакытлы матбугатта яңа имзалар тууын хәбәр итә. Ж. Вәлиди, М. Хәнәфиләр белән беррәттән, “... әүвәлге бер әсәр тәнкыйдиясе һәм "Ил"дәге берничә фельетоны илә ихтыяжсыз зиһеннәргә кереп утырган Нәжип Гасрый әфәндене зикер итми Үтү (искә төшерми Үтү. - acc. Т.Г.) хисапның тулылыгына, шөбһәсез, кимчелек китергән булыр иде" [Ибраһимов, б. 201] - дип яза. Г. Сәгъди "Бездә әдәби тәнкыйть" мәкаләсендә, 1910 елларда әдәби тәнкыйть мәйданына чыккан тәнкыйтьчеләр арасында $Г$. Ибраһимов, Ж. Вәлиди, Г. Рәхим, Х. Искәндәров, Х. Кәримовлар белән беррәттән, Н. Гасрыйның исемен дә атый [Сәгъди, 1927, б. 18].

Татар әдәбият белеменең бер тармагы булган әдәбият тарихының фән буларак формалашуы XX гасырның беренче чирегенә нисбәт ителә. 1910 еллар вакытлы матбугатында татар әдәбиятының үсешен элгәрге чорлардан алып хәзерге көннәргә кадәр тарихи планда яктырткан, шулай ук әдәби барышның үзгәреш тенденцияләрен һәм яңа әдәби күренешләрне аерып чыгарып, аларны бәяләу омтылышы белән язылган $\mathrm{P}$. Фәхретдинов, Ф. Кәрими, Ж. Вәлиди, Ф. Әмирхан, Г. Исхакый, Г. Ибраһимов, Х. Кәримов, Н. Гасрый һ.б.ларның мәкаләләре басыла.

Нәжип Гасрыйның яңарыш чоры әдәбиятының сыйфади үзгәрешләре чагылган «Россия татарларының уянуы həм аларның әдәбияты» (Пробуждение русских татар и их литература) дигән күләмле мәкаләсе «Современник» журналының 1911 ел 4 санында дөнья күрә. Татар әдәбиятының классик язучысы Г. Исхакый белән рус әдәбиятының күренекле әдибе А.М. Горький арасында жылы hәм ижади дуслык жепләре урнаша. Алар 1911 елдан алып 1923 елларга кадәр хат алышалар. A.M. Горький татар әдәбиятында күзәтелгән тенденцияләр, аның төп сыйфатлары, күренекле вәкилләре хакында Гаяз Исхакыйдан «Современник» журналына мәкалә язуны 
үтенә. Исхакыйның бу еллар тормышы аеруча мәшәкатьле hәм катлаулы булуы белән аерылып тора. Хатларының берсендә: «Татар әдәбиятының торышы турында очеркны тиз арада салырмын» [Исхакый, 2013, б. 11], - дип вәгъдә бирсә дә, билгеле сәбәпләр аркасында сүзендә тора алмый. Олуг әдип бу эшне үзенең мәсләктәше $\mathrm{H}$. Гасрыйга йөкли. Татарча язылган мәкалә, Г. Свердлов тарафыннан русчага тәржемә ителеп, журналда басылып чыга.

Европа мәдәнияте һәм әдәбияты тәэсирендә булган Төркиядә белем алган Н. Гасрый милли әдәбият тарихын Россия ижтимагый-сәяси вазгыяте һəм тарихи вакыйгалар һәм аларның татар галәменә алып килгән үзгәрешләре контекстында тикшерә. Күләмле мәкаләнең башлам өлешендә татар халкының аянычлы тарихы, ижтимагый-рухи фикеренең хәрәкәте әтрафлы итеп бәян ителә. Автор тарафыннан ижтимагый-сәяси үзгәрешләрнең баскычлары билгеләнә: сәүдә һәм игенчелек белән актив рәвештә шөгыльләнү, Үзәк Азия , Төркестан белән мәдәни бәйләнешләр торгызылу, Екатерина II реформалары һ.б. [Неджиб, 1911, c. 166-179].

Н. Гасрый татар халкының ижтимагый хәятенә һәм икътисади эшчәнлегендә күзәтелгән жанлануны бәяләгәннән соң, мәдәни-әдәби тормыштагы сыйфади үзгәрешләрне анализлауга күчә. XIX гасыр башында Казанда беренче татар типографиясе ачыла. Ислам динендәге инкыйлабны $\mathrm{H}$. Гасрый мәгърифәтче, дин галиме, тарихчы, фәлсәфәче Шиһабетдин Мәржани эшчәнлеге белән бәйләп карый. Яңа татар әдәбиятына нигез салучы - Каюм Насыйри алга чыга. Каюм Насыйри күпъяклы эшчәнлегенең әһәмиятле юнәлешләреннән берсе - аның татар матбугатын Төркестан мистикасы монополиясеннән, татар телен чит телләр тәэсиреннән арындыру өлкәсендәге фидакарь хезмәте [Неджиб, 1911, с. 170]. Тәнкыйтьче татар әдәбиятындагы яңарыш сыйфатын Ш. Мәржанинең дини реформаторлык эшчәнлеге йогынтысында татарларда туган фикер уяну белән сәбәпле бәйләнештә карый.

1883 елда Бакчасарайда Исмәгыйль Гаспралы «Тәржеман» - «Переводчикъ» дигән беренче татар газетасын чыгара башлый. Тәнкыйтьче бу зыялының татар халкының ижтимагый-рухи яңарышында уйнаган гажәеп зур ролен яз хәбәрчесе - карлыгачка тиңли. Газетасының беренче саныннан ук ул татар халкын европалашуга «чакыра» башлый, мәдрәсәләргә Үзгәрешләр кертү кирәклеген әйтә, иске укыту ысулларын тәнкыйтьли. Үз әсәрләрендә милли чынбарлыкны реалистик детальләрдә сурәтли башлаган Заһир Бигиев, Риза казый Фәхретдинов һәм Фатих Кәримиләрнең әдәби эшчәнлеге югары бәяләнә. Әдәби, публицистик әсәрләренең XIX гасыр соңгы чиреге татар әдәбиятын идея эчтәлеге hәм форма ягыннан яңартудагы рольләре күрсәтелә.

Н. Гасрый татар әдәбияты юллар чатында торган чакта Гаяз Исхакый ижаты белән татар әдәбияты тарихында яңа дәвер башлануын ассызыклый. «Татар әдәбияты билгесез юллар чатында торган вакытта 1897 елда әдәби аренага Гаяз Исхакый чыга. Ул күренү белән, татар әдәбияты үсешендә яңа дәвер, татар матур әдәбиятының үсеше, реализм юлында кискен борылыш еллары башлана» [Неджиб, 1911, с. 173] Тәнкыйтьче, әдәбият проблемаларыннан тыш игътибарын татар теле мәсьәләләренә дә юнәлтеп, Гаяз Исхакыйны татар әдәбиятына нигез салучы, ә “татар әдәби теленең атасы" дип билгели. Беренче рус инкыйлабы белән ташкын булып поэзиягә килеп кергән шагыйрьләр арасыннан ике шагыйрьне - Габдулла Тукай һәм Сәгыйт Рәмиевне аерып ала. 1905-1910 еллар шигъриятендә, халык теләк-омтылышлары, моң-зарлары белән сугарылып, татар тормышын тулы сурәтләргә омтылган халыкчан реалистик поэзияне һәм, мул поэтик бизәкләргә төреп, лирик-шәхси кичерешләрне калкытып куйган романтик поэзия юнәлешләрен билгели.

1910 елларда, милли рамкаларда гына калмыйча, Ауропа киңлекләренә омтылган сүз сәнгатен бәяләү һәм аның үсеш юлларын билгеләү бурычы йөкләнгән татар әдәби тәнкыйтен камилләштеру, аның дәрәжәсен күтәрү мәсьәләсе көн тәртибенә куела. Бу уңайдан аның “Әдәбиятымыз мөнәкъкыйдкә мохтаж” (1913) мәкаләсе языла. Н. Гасрый дөнья һәм төрки-татар әдәбиятында шартлыромантик кулланылышның гаять бай, үзенчәлекле традицияләре булган бакча, cy, яктылык символларына мөрәжәгать итеп, әдәби тәнкыйтьнең матур әдәбият үсешендә тоткан роле, тәнкыйтьченең абруе турында Үз бәя-хөкемнәре белән уртаклаша [Гасрый, Әдәбиятымыз..., 1913]. Автор тәнкыйтьне “әдәбиятның тәрәккыйсендә иң әһәмиятле бер гамәл” буларак карый, “матур әдәбият 
әсәрләрен бәяләүдә әдәби тәнкыйтьтә объективлык принцибын тәкъдим итә" [Мухамадиев, с. 16].

H. Гасрыйның татар әдәбиятының яңарышында хәлиткеч роль уйнаган язучыларның күренекле әсәрләрен яисә аларның тулаем ижатын бәяләгән мәкаләләре дә басыла. Аның ижат портреты жанрындагы “Шимали төрек әдипләреннән Гаяз Исхакый" язмасы дөнья күрә. Тәнкыйтьченең әдәбиэстетик карашлары, әдәбият-сәнгатькә мөнәсәбәте мәсләктәше Г. Исхакый тәэсирендә формалаша. Ул культура-тарих мәктәбенең төп кагыйдәсенә нигезләнеп, сүз сәнгатенең вазифасын милләткә хезмәт итүдә, аның үсешенә файда итүдә билгели: “... мөхәррирнең әсәр язудан максаты “сәнгать күрсәтү” түгел, ә мәгънәдер” [Исхакый, 2001, 8 т., 164].

Н. Гасрый язучы ижатының идея-эстетик үзенчәлекләрен, жанр таләбенчә, аның тормыш баскычларындагы мөһим вакыйгалар белән синтезлап алып бара. Мәкалә авторы Исхакыйның әлеге вакытка кадәрге әдәби эшчәнлеген ике чорга бүлә: беренчесе “милләтпәрвәрлек”, икенчесе

“гавампәрвәрлек”. hәр чорның ижат жимешләрен атый һәм аерым берләренә жентекле анализ ясый. "Ике йөз елдан соң инкыйраз" повестен беренче ижат чорының иң күренекле әсәре дип саный. Г. Исхакыйның милли сүз сәнгате тарихындагы ролен “яшь татар әдәбиятына ныклы нигез коручы һәм ул әдәбиятның иң зур вәкиле" төсендә югары бәяли, ижатының реалистик стилен hәм халыкчан рухын, гәүдәләнгән темаларның ижтимагый-милли характерын аерып куя.

Г. Ибраһимовның сәнгатьчә эшләнеше югары булмаган "Яшьләр хәятеннән бер ләүхә" хикәясе басылып чыгып, 5-6 ел узганнан соң, тәнкыйди һәм ижтимагый фикернең игътибарын үзенә тарта һәм вакытлы матбугатта С. Рәмиев, Ж. Вәлиди язмалары дөнья күрә. Н. Гасрый “Ил” газетасында Г. Ибраһимов хикәясенә язылган "Яшьләр хәятеннән бер ләүхә” рецензиясен бастыра [Гасрый, 1914, Яшьләр хәятыннан...]. Автор әсәрнең проблематикасы уңаеннан XIX - XX гасыр чикләрендә татар яшьләре, алардагы фикер хәрәкәтенә кыскача күзәтү ясап, “фәлсәфә”, “милләтчелек”, “инсаниятчелек” үсеш-үзгәреш баскычларын аерып чыгара.

Ике гасыр чигендәге татар яшьләре хәрәкәте тарихына характеристика биргәннән соң, автор, бу хәрәкәтнең гәүдәләнеше булган
Сәлимнең образ буларак бирелешен бәяли. Хикәядә сурәтләнгән вакыйгаларның герой рухында һәм мәсләкләрендәге үзгәрешләрне ачмавын, фикри күчешләрнең Сәлим эшчәнлеге аша исбатланмавын ассызыклый. Язучы “гали рухлы” дип тәкъдим иткән Сәлимнең өч-дүрт ел эчендә туктаусыз мәсләк алмаштыруы аның характер сыйфатына туры килмәвен күрсәтә [Гасрый, 1914, Яшьләр хәятыннан...].

Н. Гасрыйның рухи мирасында милли шигърият, аның асылы, гомуми торышы һәм үсеш тенденцияләре, татар поэзиясенең аерым вәкилләре ижаты хакында язмалар да бар. Шундыйларның берсе 3. Бурнашеваның дөнья күргән шигырьләре китабына рецензия-мәкалә жанрында язылып, “Ил” газетасының 1915 елгы 4, 11 март саннарында басылган “Гыйффәт туташ шигырьләре” дип атала. Ул татар матбугатында хатын-кыз шагыйрә ижатына багышланган тәүге күләмле язма булуы, татар дөньясында Н. Гасрыйның 3. Бурнашева хакында беренче сүзне әйтүе ягыннан да игътибарга лаек.

Мәкаләнең башлам өлешендә Н. Гасрый поэзия, аның асылы, сәнгатьнең башка төрләреннән, әйтик музыка, рәсем, скульптурадан аерымлыклары, милли шигъриятнең үсеш тенденцияләре турында үз карашлары белән уртаклаша. Тәнкыйтьче язучылык hөнәре, шагыйрьлек сәләте, талант турында уйланганда, Г. Ибраһимов нигез салган "рухиятчеләр" мәктәбе сызыгына төшеп, аның табигать тарафыннан бирелүен, илаһи көч булуын ассызыклый һәм шул ук вакытта талантның тәрбия ителүен, гыйльми-нәзари мәгълүмат белән ныгытылуын да зарури шарт буларак карый [Гасрый, 1915, Гыйффәт туташ...].

Язма авторы шушы гыйльми күзаллаулары яссылыгында Гыйффәт туташның әсәрләрен анализлауга күчә. Н. Гасрый 3. Бурнашеваның шигырь жыентыкларын 1914 елның шигърият күгендә “моңлы, кадерле йолдызлар” рәвешендә бәяли һәм аны татар поэзиясендә хис-калеб шагыйрәсе, “тойгылар шагыйрәсе” буларак карый. Шагыйрәнең шәхси, индивидуаль күңел кичерешләрен жырлавына басым ясала. Шул рәвешле Гыйффәт туташның шигърияткә килү, әсәрләренең идея-эчтәлеген билгеләгән кичерешләрнең сәбәпләре күрсәтелә.

Н. Гасрый рецензия-мәкаләсендә әдәби йогынты, әдәби тәэсир, әдәбиятара бәйләнешләр, XX гасырның урталарында 
фәнни әйләнешкә кергән интертекстуальлек мәсьәләсен күтәрә һәм ул бу фәнни проблеманы Гыйффәт туташ һәм күренекле татар әдәбияты классигы, шагыйрь Г. Тукай шигъриятләре мисалында карый. Тәнкыйтьче Гыйффәт туташ лирикасына шагыйрь ижатының йогынтысы аз булуын искәртә. Тукай ижатының замандашлары поэзиясенең идея-эстетик үзенчәлекләренə һәм тел-өслүбенә йогынтысын тикшергән Г. Сәгъди, киресенчә, 3. Бурнашеваның Тукайның шәкерте булуын раслый [Сәгъди, 1923, б. 6]. 3. Бурнашева Тукай шигъри бишегендә тәрбияләнгән, “Тукай поэтик мәктәбе” шагыйрәсе. Гыйффәт туташ лирикасы белән Г. Тукай ижаты арасында эчкемәгънәви һәм тышкы бәйләнеш бик тә көчле. Шагыйрә үз поэзиясен, ижат тәжрибәсен бөек Тукайдан һич тә аермый; киресенчә, шагыйрьнең үзенә ясаган бәрәкәтле тәэсире турында горурланып яза һәм үзен Тукай традицияләре дәвамчысы дип саный.

Язманың соңгы өлешендә Н. Гасрый шагыйрә әсәрләренең эстетик табигатен тикшереп, идея-эстетик хосусиятләрен барлый. Шигырьләрендә шагыйрә-авторның жаны, рухы, калбе кичерешләре чагылу, образлылык, сурәтлелектән тыш тел-өслүб матурлыгы, сөйләм жиңеллеге, нәфислеге бизмәннәренә таянып, Гыйффәт туташның романтик поэзия вәкиле булуы хакында төп гомумиләштерүләрнең берсен ясый. Татар әдәбиятында яңа тип романтизмны биек үрләргә меңгерәчәк күңелнең хатын-кыз күңеле булуына чын күңелдән сөенә.

Н. Гасрыйның тәнкыйди мирасында элгәрге чор әдәби әсәрләрен бәяләгән язмалар да бар. Аның мәгърифәтче язучы М. Акъегетнең күренекле романына багышланган күләмле "Хисаметдин менла (Акъегетзадә Муса әсәре). Бер тәхлил әдәби" исемле рецензиясе “Аң" журналының 1915 елның ике санны берләштергән 9-10, 23-24 саннарында дөнья күрә. Тәнкыйтьче М. Акъегетнең романын әдәби барыш, аның үсеш закончалыклары хакындагы гыйльми күзаллаулары нигезендә яңа заман сүз сәнгатенең башлангычы, беренче “бисмилласы” дип бәяли. Аның бу карашы меңъелдан артык тарихы булган татар әдәбиятының дәверләрен аерып чыгарган күренекле әдәбият галиме Г. Ибраһимов тарафыннан яклана. Галим борынгы кадим дәвердән соң килгән жәдит дәверенең $\mathrm{M}$. Акъегетнең "Хисаметдин менла" романы белән башлануын ассызыклый: “Икенче - жәдит әдәбият: бу дәвер моннан 30 ел элек чыккан Муса Акъегетзадә әфәнденең "Хисаметдин менла"сы белән башлана" [Ибраһимов, 1978, б. 290].

Н. Гасрый культура-тарих мәктәбенең кагыйдәсе буенча татар әдәбиятының вазифасын милләткә хезмәт итүдә, аның мәдәни үсешенә файдалы булуда билгели: “Без шигырь вә әдәбиятка сәнгать күзе белән карый алмыйбыз; без әдәбиятны эшләтергә, аннан файдаланырга, аннан матди файда күрергә тотынабыз. Яңа әдәбиятымызның беренче сәхифәсен тәшкил иткән "Хисаметдин менла" моңарга кисеп куйган үрнәк” [Гасрый, 1915, Хисаметдин менла, б. 192].

Н. Гасрый яңа әдәбиятның үрнәге булган бу әсәргә “иске әдәбият"ның фикри-мәгънәви һәм форма ягыннан йогынты ясавын билгели. Автор карашынча, урта гасырлар әдәбияты чыгтай әдәбияты һәм “жәнүби - госманлы әдәбият”лары белән тыгыз бәйләнештә яши. Ул шушы мөнәсәбәт илә ике әдәбиятның да тарихына кыскача күзәтү ясый. Ике әдәбиятның үсеш баскычлары, үзгәреш тенденцияләре, күренекле язучылары, аларның ижатында гәүдәләнгән тема-мотивлар, телөслүб үзенчәлекләре, образ-тасвирлар аерып чыгарыла.

Тарихи экскурстан соң $\mathrm{H}$. Гасрый “Хисаметдин менла"ны бәяләүгә күчеп, анда шул чорның актуаль ижтимагый һәм милли проблемалары күтәрелүен яза. Язучыда милли тойгының 3. Бигиевкә, Р. Фәхретдиновка караганда көчле булуын биографик метод принципларына нигезләнеп аңлата, тормышындагы аерым фактлар белән бәйли: “Анда милли хиснең иртә яфрак яруына, бер яктан, “Тәржеман” сәбәп булган булса, икенче яктан, рус мәктәбендәге тәрбиянең гакес (кире. - T.Г.) тәэсире, яки аның Акъегет укыган вакыттагы тәэсирсезлеге" [Гасрый, 1915, Хисаметдин менла, б. 193]. Әдәби әсәрдә үзәккә шәхес иреге, шәхес азатлыгы проблемасының куелуын күрсәтә [Татар әдәбияты, 1985, б. 293]. Ул романның төп каһарманнары Хәнифә һәм Хисаметдин менлаларның дөньяга карашлары һәм гамәлләре аша күрсәтелә. Рецензент карашынча, шәхес иреге кеше тормышындагы иң кыйммәтле сыйфат: “Инсан мәгыйшәтендә бер бәһалы вә яхшы шәй - хөррияттер: без үз хөрриятемезне саклый белермез" [Гасрый, 1915, Хисаметдин менла, б. 419 ]. Шәхес иреге мәсьәләсе милли чынбарлыкта хатын-кыз 
урыны, никах иреге, хатын-кызларга белем бирү проблемалары белән үрелеп китә. Мәкалә авторы Хәнифәнең, P. Фәхретдиновның "Сәлимә яки гыйффәт" әсәрендәге идеаллаштырылган Сәлимәдән аермалы буларак, үз бәхете өчен көрәшүен ассызыклый hәм аны Г. Исхакыйның “Алдым-бирдем" (1907) драмасының Үзәк каһарманы Галия белән янәшә куя.

Алга таба мәкалә авторы Хисаметдин менлага характеристика бирә. Ул Төркиядә укып кайтып, үз өендә яңа ысул белән балалар укыта һәм тиз арада укырга, язарга өйрәнгән балаларның аталарында яклау таба. Аның өстенә ул булдыклы һәм һөнәрле егет, игенчелек белән шөгыльләнә [Гасрый, 1915, Хисаметдин менла, б. 193]. Тәнкыйтьче М. Акъегетзадәнең мәгърифәтчелек реализмы агымы принципларыннан чыгып үз геройларын мәгълүм бер идеал яктылыгында сурәтләвен ассызыклый. Язучы геройларның югары әхлаклылыгын иң мөһим сыйфат дип саный.

H. Гасрый романда вакыйгалар үстерелешен тәэмин иткән тискәре геройлар Бикбулат мулла, авылның иң зур бае Гали бәк Жаватов белән таныштыра. Тәнкыйтьче Бикбулат мулланы анализлаганда, “тип” терминына мөрәжәгать итә, ягъни ул шул чорның иске карашлы, кадим, әхлаксыз руханиларның гомумиләштерелгән тибы [Гасрый, 1915, Хисаметдин менла, б. 416]. Укуукыту ысулы, белем бирүнең нәтижәлелеге мәсьәләсенә нисбәтле Бикбулат менла белән Хисаметдин менла арасында туган төп конфликт күрсәтелә. Үзәк конфликтның ярдәмче каршылыклар белән һәрдаим тирәнәйтелеп баруына басым ясала.

H. Гасрый "Хисаметдин менла" романындагы Әбүзәр бәкне, Хисаметдин менланы, Хәнифә туташны хәзерге вакытта татар зыялылары төркемендә барлыкка килгән милләтпәрвәрләрнең, милләт хадимнәренең прототиплары, образлары дип карый. Ф. Әмирханның “Тигезсезләр” (1914) драмасы дөнья күргәч, татар чынбарлыгында Рөкыяләр житешүен инкарь итеп, Ф. Сәйфи-Казанлының “Ялтыравыклы ялган” (1916) бәхәсле мәкаләсе басыла. Аңа жавап төсендә Х. Искәндәровның Тигезсезләр"дә Рөкыя" (1916) язмасы нәшер ителә. Ул анда, Н. Гасрый фикерләренә аваздаш карашлар үткәреп, рухи яңарыш юлындагы татар тормышында Рөкыя, Камилә, Фатыймаларның тәрбияләнә алуын, хәтта аларның инде татар галәмендә барлыгын раслый (Кара: [Гыйлажев, 2008, б. 92-93]).

Н. Гасрый М. Акъегетзадә әсәренең сәнгати үзенчәлекләренә дә бәя бирә. Ул язучының хат алымына максатчан мөрәжәгать итүен уңай бәяли. Хат алышуның төп каһарманнарның күңел кичерешләрен, характерларын, карашларын, үзара мөнәсәбәтләрен тулырак ачу вазифасын билгели. Шулай ук хатлар саф, илаһи мәхәббәтне, сөю-сөелү хисләрен зурлауга да хезмәт итә. Романда авыл халкы тормышының реаль детальләрдә гәүдәләнеше, аның яшәү рәвеше, этнографик үзенчәлекләре, туй йолалары, милли гореф-гадәтләре сурәтләнеше билгеләнә. Күңел монологларының төп каһарман Хәнифәнең эчке дөньясын, психологик кичерешләрен ачудагы роле әйтелә. Үз теләгеннән башка яратмаган кешегә бирелгән Хәнифәнең туй көннәре алдыннан булган борчылулы күнел халәте монолог ярдәмендә гәүдәләнә. Табигать тасвирларының, пейзаж алымының вакыйгалар вакытын һәм урынын конкретлаштырудан тыш, геройларның психологиясен ачу идея-эстетик вазифасын билгели.

H. Гасрый 1917 елгы Октябрь инкыйлабыннан соң төзелә башлаган социалистик жәмгыятьтә үз урынын табарга омтыла. Яңа социаль һәм мәдәни шатларда әдәбиятка һәм сәнгатькә куелган яңа таләпләр ноктасыннан әдәби әсәрләргә һәм фәнни хезмәтләргә бәя бирә. Аның “Эшче" газетасының 1926 ел 20 гыйнвар санында Г. Нигъмәтинең “Әдәбият мәйданында” (1925) дигән монографиясенә рецензиясе басылып чыга. Тәнкыйтьче китапның кыйммәтен 1880 еллардан алып хәзерге көннәргә кадәр Гареб мәдәнияте йогынтысында үскән татар әдәбияты ирешкән казанышларны гомумиләштерүдә, аларны билгеле бер системага салуда бәяли. Ул галимнең, чит ил hәм рус галимнәре хезмәтләренә таянып, реализм, романтизм, символизм, имажинизм, футуризм методларының типологик характеристикасын бирүен һәм шуның нигезендә татар классик һәм яшь язучыларның ижатларын анализлавын билгели. Рецензент Г. Нигъмәтинең әдәби хәрәкәтне, әдәби әсәрне тикшеру методикасының аерым сыйфатларын барлый, ягъни аның әдәби күренешкә комплекслы һәм системалы якын килүен күрсәтә.

Тәнкыйтьче карашынча, Г. Нигъмәти матур әдәбиятны башка сәнгать төрләре, сынлы сәнгать, жыр һәм музыка белән бәйләнештә 
шәрехли. Э. Нигъмәтуллин Н. Гасрыйның фәнни ижатны бәяләү методикасының үзенчәлеген нәкъ шушы ноктадан бәяли: “Әдәбиятчы Нәжип Гасрый китапның гомумиләштеру, нәзари сыйфатын hәм авторның әдәби ижатны эстетика һәм башка сәнгать төрләре, мәсәлән, музыка, сынлы сәнгать белән бәйләп тикшеру омтылышын ассызыклап, аны соклану хисе белән кабул итә" (сүзгә-сүз тәрж. - Т.Г.) [Галимджан Нигмати..., c. 222], дип яза Э. Нигъмәтуллин. Мәкалә авторы үз күзәтүләре нигезендә татар нәфис әдәбияты гына түгел, ә музыка, рәсем сәнгатьләре дә "Гареб сәнаигы нәфисә сараенда" үзенә лаек урын алачак дигән нәтижәгә килә.

Тормыш-чынбарлыкны hәм ижатчының рухын, хис-хыялын сурәтләгән реализм һәм романтизм юнәлешләрен үзләштергән татар әдәбияты дөньяны танып-белү, яшәешнең асылына төшенүнең яңа юлларын эзли башлый. Ижат әһелләре фәлсәфи тәгълиматларны, гыйльми концепцияләрне, әдәби-эстетик системаларны өйрәнәләр. Яңа мәгънәви эчтәлекне гәүдәләндерү, сүз сәнгатен нәфисрәк həм тәэсирлерәк итү максатыннан, Ауропа һəм Рус мәдәниятләрендә модернистик алымнарга һәм сурәтләү чараларына мөрәжәгать итәләр. Татар әдәбиятындагы яңа дулкынга Г. Ибраһимов, Ф. Әмирхан, С. Рәмиев, Дәрдемәнд, Ш. Камаллар белән бергә, әдәби ижатка дөньяви уку йортларында белем алган $\Gamma$. Рәхим. $Г$. Гобәйдуллин, М. Кайбышев һәм башкалар кушылып китә. Алар арасында Н. Гасрый да бар.

H. Гасрыйның "Гыйшкым хәрабәләре" (1916) исемле әсәре Шәрык һәм Гареб сүз сәнгатьләре эстетик казанышлары hәм традицияләре синтезында язылган. Сабый вакыттан ук яраткан Искәндәрнең Ләйләгә гашыйк булуы Гөлнар ханымны авыр кичерешләргә, ялгызлыкка дучар итә. Аның сызланулы күңел халәте көзге табигать, агачлардан өзелеп төшкән сары яфраклар фонында тасвирлана. Көз, яз, кыш фасыллары, бакча, яфрак образлары татар әдәбиятында бик актив кулланылып, фәлсәфи мәгънә белдерүгә хезмәт итәләр, “.. көзге бакча үлем, өметләр өзелү, мәхәббәт һәм бәхеткә булган ышанычның юкка чыгуын искәртә" [Заһидуллина, 2007, б. 11]. Көчле позициягә ия булып, әсәрнең исеменә чыгарылган хәрабә символы кире кагылган мәхәббәткә, яшәү гаме һәм тормыш яме югалуга ишарә ясый. Әсәрдә жан яраткан бер була, чын сөю, ярату хыянәтне кичерә алмый дигән фәлсәфи фикер үткәрелә. Хикәядә мәхәббәт темасы һәм мәгъшукаләр матурлыгы илаһилаштырылып, Шәрык һәм Гареб мәдәниятләре синтезында күрсәтелә.

Чор сүз сәнгате эзләнүләренә, бу юлда ясалган тәжрибәләргә кушылып, Н. Гасрый яшәешнең акыл белән аңлап бетеру мөмкин булмаган яшәу һәм үлем, фанилык һәм мәңгелек проблемаларын яктырткан "Мәзарстанда" (1916) әсәрен яза. Көзге матур көннәрнең берсендә хикәяләүче үлеменең сәбәбе ачыкланмаган сөйгән кызы Ләмиганның каберен зыярәт кылырга дип өеннән чыга. Ул зираттагы серле тынлыкны бозган бер кыз баланың Коръән укыган кебек ишетелгән тавыш астында юлын дәвам итә. Герой - күптән вафат булган карт, алкоголик ире суеп үтергән хатын, ике егеткә гашыйк булып үзенең үлеменә сәбәпче булган кыз, Үз-үзенә кул салган егет каберләре аркылы уза. Ниһаять, Ләмиган кабере янына барып житеп, үткән бәхетле көннәрне күзаллап, күз яшьләре түгә. Егетнең күңел монологында сөю хисләренә, яшьлек мәхәббәте Ләмиган матурлыгына мәдхия укыла. Алга таба автор тарафыннан аң белән кабул итеп бетеру мөмкин булмаган дини-мистик күренешләр аша мәгъшука образы илаһилаштырыла: кызның кабер сакчысы итеп утыртылган “яшь, матур, чинар агачының яфраклары тәсбих әйтә” башлыйлар, кыз кабере өстеннән “нурани ак бер шәүлә күтәрелеп”, егетне билгесез матурлыгы белән сарып ала. Күпмедер вакыт серле халәттәге хикәяләүче үз хәленә килә һәм, тынычланып, кайтырга дип юлга чыга.

Озак вакытлар үтүдән ташлары мүкләнеп беткән кабер янында таш астыннан карт укыган аять ишетелә, дөнья кинәт үзгәреп, зиратта кыямәт башлана. Үлекләр кубарылып жир өстенә чыга"; “зур, ак сакаллы, ак кашлары күзләрен каплап тора торган бер карт" таш өстенә утырган да, сүрә укый; “мәгъшука кайгысыннан үзен үзе чалган яшь егет кәфенен сөйрәп" кабер ташының өстенә чыгып, башын кулларына куеп утырган h.б.лар. Төрле тарафтан, аһ-зарлар, төрле тавышлар ишетелгәндәй була.

Г. Сәгъди бу әсәрне, Мәскәүдә нәшер ителеп, бүген дә фәнни кыйммәтен югалтмаган "Символизм турында" (1931) монографиясендә чәчмәдә “урыс әдәбияты тәэсирендәге" символизм үрнәге буларак бәяли. "Нәжип 
Гасрыйның “Мәзарстанда” (“Аң”, №5, 1916) дигән һәм бик көчле каләм белән язылган лирик хикәясе шуның ачык мисалы. Ул бу юлда иң характерлы бер хикәя" [Сәгъди, 1931, б. 113-114]. Галим язучының мондый эчтәлектәге хикәяләренең француз декадент әдәбияты тәэсире астындагы госманлы сүз сәнгатенең күренекле язучысы Халит Зыяның "Кабердән тавышлар" әсәре йогынтысында ижат ителүен күрсәтә.

Символизм агымында язылган хикәянең яшерен эчтәлеге символик образлар, сурәтләр ярдәмендә белдерелә. Әсәр “Аһ сихерле, серле хәят! Син яшим! - дип, комга басасың; ул синең аяк астыннан тая, кача бара!” дигән хисси-эмоциональ яңгырашлы, шартлы сурәтләргә бай жөмлә белән каймаланып алынган. Ул яшәү, кеше тормышы, аның теләкомтылышлары ялган, иллюзия генә дигән экзистенциаль фикерне белдерүгә хезмәт итә. "Кыямәт көне" каберләреннән кубарылып чыккан үлекләр арасында кеше гомерен өзгән, дин-шәригать кануннарына, дини өйрәтүләргә буйсынмыйча, Үз-үзләренә кул салганнар бар. Н. Гасрый Аллаһы Тәгалә каршында олы гөнаһлар кылган кешеләргә теге дөньяда жиңел түгел, алар анда тынычлыкка ирешә алмыйлар дигән дини күзаллауны да раслый. Әсәрдәге образ-сүзләрнең символик табигатенә, әсәрнең фәлсәфи-экзистенциаль эчтәлегенә әдәбият галиме Ф. Бәширов та игътибар итә [Бәширов, б. 248].

Н. Гасрыйның, милли тарихка мөрәжәгать итеп, ижтимагый-фәлсәфи фикерләрен сәнгатьчә гәүдәләндергән “Соңгыр хан түбәсендә" дигән хикәясе “Аң” журналында 1916 елның 2 санында басыла. Кечкенәдән әбисеннән Соңгыр хан турында әкиятләр тыңлап үскән малай, зур шәкерт булгач, ханның образын хыялында тудыра. Мөселманнар ханы булган Соңгыр хан, атланып йөри торган аргамагы картайгач, чикләвек агачыннан көмеш белән каплатылган ишекле абзар салдыра. Рәхимле һәм шәфкатьле хан Yз сараенда фәкыйрьләрне һәм мескеннәрне жыеп кунак итә, ә фәкыйрь-фокара ашап-эчеп туйганнан соң, аларга берәр аяк-касә кымыз бирелә, соңыннан хан заманында сугылган акчалар өләшенә. Халык ханга рәхмәт йөзеннән аның сәламәтлегенә кычкырып дога кыла. Хан $\mathrm{Y}^{3}$ сараенда шул заманның галимнәрен, мөнәжәтчеләрен, Гали хәзрәтне, Сәид Баттал Газине, думрада көйләп жыр әйтүчеләрне, сарай шагыйрьләрен тоткан. Хан картаеп үлгәч, аның табутын ука белән урап, шәһәрдән зыярәткә хәтле көмеш акчалар чәчеп алып килеп, кызыл түбәгә жирлиләр.

Хикәядәге Соңъьыр хан төрле мәгънәви яссылыкта укылу мөмкинлегенә ия символ булып тора. Д. Заһидуллина аны “милләтне яшәткән, дәүләтчелекне саклаган, бүген дә авторлар шушы идеалга милләтне уяту, терелтү миссиясен йөкләгән” “нәби” төшенчәсе белән бәйләп карый [Заһидуллина, 2003, б. 59]. Аның мәгьнәсен Урта гасырлар татар әдәбиятында гәүдәләнгән гадел хөкемдар идеясе, “камил инсан" өйрәтүе, мөселман мәдәниятендә пәйгамбәрләрне һәм галимнәрне белдергән “көтүчеләр" мәгънәсендә дә шәрехләргә мөмкин. Әсәр ахырында шәкерт күзалдында “агарган кашлары күзләренә төшкән” Соңгыр хан рәсеме жанландырыла һәм аның күңелен милли хис били, тарихи хәтер уяна: “Мине әллә нинди мөбһәм (билгесез. - acc. Т.Г.) бер тарихи, милли тәэсир чорнап алып кувәи хыялиямне татар тарихының киңлекләренә, парлаклыкларына (шанлылыкларына. - acc. Т.Г.) таба суза: Ханнар, Хан заманнары..." [Гасрый, 1916, Соңгыр түбәсендә, б. 33]. Менә бу алым символның ижтимагый-милли мәгънәсен көчәйтә. Н. Гасрый бу хикәясендә дә татар милләтен инкыйраздан саклап калуга, мәдәниләштерүгә хезмәт итүче "рухи юлбашчылар", голәмалар, шәхесләр һәм үзе дә шуның бер өлеше булган язучылар житештерү мәсьәләсен сәнгати формада гәүдәләндерә.

XX гасыр башында - Исхакыйлар Тукайлар чорында - мөстәкыйль үсеш сукмагына чыккан татар публицистикасын үстерүгә Н. Гасрый да Үз өлешен кертә. Публицист замандашларыннан аермалы буларак, марксизм тәгълиматының ижтимагый үсеш сыйнфый көрәш белән тәэмин ителә дигән постулатына каршы килеп, тарихи барышта аерым шәхесләрнең роле турында уйлана. Шуңа күрә аның бер шәлкем публицистик язмалары татар халкының кискен тарихи hәм ижтимагый үзгәрешләр чорында, “тарихка булышучы, тарихның акрын гына, форсат белән генә эшләячәк эшен ашыктыручы куәтләр"гә [Вәлиди, б. 119] багышланган. Бу типтагы мәкаләләр шәлкемен, татар әдәбиятына сыйфат үзгәрешләре алып килеп, аны дөнья аренасына чыгарган халык шагыйре $Г$. Тукайның вакытсыз үлеме мөнәсәбәте белән “Идел" газетасының 1913 ел 5 апрелендә басылган “Тукаев вафат” тәгъзиясе башлап жибәрә. Ул, мәрсия жанрына хас булганча, 
купшы, бизәкле тел белән язылып, Тукайны зурлый. Әмма язма, бөек шагыйрьне югалту белән бәйле юксыну, сыктау хисләре белән сугарылу сәбәпле, некролог-сыктау жанрына якын тора [Гыйлажев, 2008, б. 175].

H. Гасрыйның Г. Тукайга ихтирами мөнәсәбәте аның рухи юлбашчысы татар реалистик әдәбиятына нигез салучы Г. Исхакый йогынтысында формалаша. Бу язма авторының фикер агышында күзәтелә. Ул некрологсыктауда шагыйрьнең үлемен тар татар мохите, шыксыз милли чынбарлыкның аңа тискәре тәэсире, татар милләтенең бөек шагыйрьгә битарафлыгы, илтифатсызлыгының нәтижәсе итеп карый.

Татар зыялысы, мәгърифәтче, төрки халыкларның мәдәниятен һәм мәгарифен үстерүгә һәм яңартуга зур көч куйган Исмәгыйль бәк Гаспралы вафат булгач, вакытлы матбугат битләрендә Ф. Әмирхан, Г. Исхакый, Г. Баттал, М. Бигиев, Г. Буби, h. Максуди, С. Максуди һәм башкалар чыгыш ясый. H. Гасрыйның да Исмәгыйль Гаспралының вафатына нисбәтле язылган “Алтын төрек егылды” дигән некролог-сыктавы 1914 елның 25 сентябрендә “Ил” газетасында басыла. Язма сыктау, кайгы хисе белән сугарылган. Мәкалә авторы милли мәгарифне яңартуга, һәр төрек-татар күңелендә милли үзаң уятуга, татар вакытлы матбугатын, матбагачылыкны үстерүгә, “фикердә, сүздә һәм эштә берлек” идеясен яклап, барлык көчен Россиядәге төрки халыкларның мәдәни үсешенә багышлаган Исмәгыйль Гаспралыны “алтын төрек” дип атый.

Н. Гасрыйның "Шиһаб хәзрәт" мәкаләсе, Шиһабетдин Мәржанинең тууына 100 ел, вафатына 25 ел тулу уңаеннан язылып, “Ил" газетасының 1915 елның 2 гыйнвар санында дөнья күрә. Юбилей мәкаләсе жанрындагы язмада публицист Ш. Мәржанинең татар халкы мәдәнияте тарихында тоткан урынын һәм гыйльми эшчәнлегенең кыйммәтен билгеләргә омтыла. Н. Гасрый Ш. Мәржани кебек олуг затның көрәш мәйданына чыгуын заман, мохит белән сәбәпле бәйләнештә аңлата [Гасрый, 1915, Шиһаб хәзрәт]. Мондый олуг затларның саны бармак белән генә санарлык булса да, татар милләтенең аларны тиешле югарылыкта зурлый, кадерли алмавына үкенү хисен белдерә.

H. Гасрый Ш. Мәржани киңкырлы эшчәнлегенең төп тармакларын аерып чыгара. Мәкалә авторы аны, иң беренче нәүбәттә, Үз чорының зур илаһият галиме, дини реформатор буларак бәяли һәм, икенчедән, галимнең милли тарихны барлау һәм язу юнәлешендәге эшчәнлеген аерып күрсәтә һәм аны “милли тарихчы” дип атый. Мәкалә авторының Ш. Мәржани турындагы фикерләре Ж. Вәлиди, Ф. Әмирхан, $Г$. Исхакый, $Г$. Тукай һәм башкаларның бәя-хөкемнәре белән аваздаш.

Н. Гасрыйның "Мәдәрәсә мәсьәләсе” (1914) мәкаләсе эчтәлеге белән, бер яктан, Г. Исхакый, Ф. Әмирхан, Г. Тукай, Г. Ибраһимов, Г. Камаллар публцистикасындагы проблематикага, икенче яктан, үзенең алда шәрехләнгән язмаларындагы тарихи барышта, милләт тормышында шәхесләр, юлбашчылар роле мәсьәләсенә барып тоташа. Мәкаләдә мәдрәсәләрдә муллалар, татарларда университетлар булмау сәбәпле, мөгаллимнәр, милләт хадимнәре житештеру проблемасы үзәккә куела. Публицист карашынча, заманнар үтү белән, муллаларның да вазифалары үзгәрә. Хәзерге заман мулласын ул төрле ракурстан карый: ул дин галиме, тормыш-көнитеш мәсьәләләрендә халыкның белемле киңәшчесе, милли мәсьәләләр белән хәбәрдар жәмәгать хадиме һ.б.лар. Бу максатларга ирешү өчен, мәдрәсәләрдә белем бирү системасын яңарту, реформалаштыру ихтыяжы туа.

Н. Гасрый “рухи юлбашчылар”ны әзерләү проблемасын милли-ижтимагый контекстта һәм күпмәдәниятле пространство кысаларында карый. Муллалар, руханиларның нәтижәле эшчәнлеге өчен кирәк булган характер сыйфатларын, яңа күнекмәләр һәм белемнәр формалаштыру ноктасыннан ул иң беренче мәдрәсәләрдә белем бирүнең структурасын һәм күләмен ачыклый. Корьән, дин-шәригать кануннарыннан мәгълүматлы булу өчен дини фәннәрне укыту кирәклеге ассызыклана; тулы канлы милләт хезмәтчесе вазифасын үтәү милли телне, имляны, татар әдбиятын һәм тарих фәннәрен өйрәнүдән башка мөмкин түгеллеге әйтелә. Мөселман руханиеның Россия гражданы булуы сәбәпле, Ватан тарихыннан хәбәрдарлыгы да шарт итеп куела. Муллага “бер рух көтүчесе, жәмәгать юлбашчысы” вазифасын башкару өчен, аның, гомуми тарих, психология, ижтимагый фәннәрдән белем һәм күнекмәләргә ия булырга тиешлеге тәкрарлана.

"Исмәгыйль бәк Гаспринский вә гомуми әдәби тел" (1914) мәкаләсе Н. Гасрый гыйльми карашларының офыгын киңәйтеп жибәрә. Ул Исмәгыйль Гаспринскийның үлеменә 90 ел 
тулу уңаеннан Ф. Гаффарова төзегән "Исмәгыйль бәк Гаспралы" китабына да урнаштырылган [Исмәгыйль бәк Гаспринский, 2004]. Язмада барлык төрки халыкларны берләштеру идеясе белән яшәгән Исмәгыйль бәк нәшер иткән “Тәржеман” газетасының телен бәяләү уңаеннан Н. Гасрыйның тел, аның асылы, үсеш үзенчәлекләре хакында карашлары гәүдәләнә. Ул телне милләтнең нигезе, аны яшәтүче һәм саклаучы мәдәниятнең бер өлеше дип карый. Исмәгыйль бәк эшчәнлегенең кыйммәтен төрек-татар милләте өчен “гомуми әдәби тел”не нигезләүдә билгели.

Төрки телләр үсеше закончалыкларына нигезләнеп, өч телне аерып чыгара: “Идел буе татарларының тел вә әдәбияты; Кавказ шивәсе вә әдәбияты; жәнүбә төрекләре теле”. Шушы телләрнең формалашу тарихын, төп хосусиятләрен, әдәбиятлары үсешен, гомуми әдәби телнең урынын һәм перспективасын билгели. Алар арасында, соңгы утыз ел эчендә барлыкка килеп, башкорт, мишәр, ногай, себер татарлары телләрен бер байрак астына туплаган, матур әдәбият тудырылган Идел буе татарларының телен аерып куя.

\section{Нәтижәләр}

1. Н. Гасрый татар мәгърифәтчеләре Ш. Мәржани, К. Насыйри, И. Гаспралыларның ижтимагый-фәлсәфи карашлары системасы тәэсирендә, Г. Исхакый, Г. Тукай, Ф. Әмирхан, Г. Ибраһимов әдәби мәктәпләрендә тәрбияләнгән икенче буын татар әдипләренең күренекле вәкиле булып тора.

2. Н. Гасрый бай һәм катлаулы тормыш юлы үтә. Россиянең һәм Төркиянең төрле баскыч дөньяви уку йортларында белем алып, теоретик әзерлекле, ижади, эзләнүчән һәм күпкырлы шәхес булып житешә һәм үзен татар халкына, милләтенә хезмәт итүгә багышлый.

3. Ул татар әдәби тәнкыйте, әдәбият тарихы, татар журналистикасы hәм публицистикасы тармакларында актив эшләп, XX гасыр башында татар халкының ижтимагый-рухи hәм мәдәни яңарышына үзеннән зур өлеш кертә. Аның ижаты “тизләтелгән үсеш юлы”на чыккан татар сүз сәнгате һəм миллилекне саклаган хәлдә ауропалашуга йөз тоткан милли мәдәният белән тыгыз бәйләнгән.

4. Н. Гасрый, гыйльми тикшеренүләрен ижтимагый барыш, татар халкы тарихы белән тыгыз бәйләнештә алып барып, әдәбиятсәнгатьне, күренекле шәхесләрне милләткә хезмәт итү, милләткә файдалы булу ноктасыннан бәяли.

\section{Йомгак}

Димәк, Нәжип Гасрый, татар әдәбиятының классиклары hәм сәләтле галимнәре белән бергә, XX гасыр башында татар халкының рухи hәм мәдәни күтәрелешендә зур роль уйный. Ул - киңкырлы hәм талантлы шәхес итеп формалаштырып, калебләрендә туган халкының ижтимагый һәм мәдәни яңарышына хезмәт итү теләге уятып та, әмма яңадан үзләрен һәлак иткән дәһшәтле һәм катлаулы XX гасыр татар зыялылары буынының берсе. H. Гасрый әдәби-эстетик hәм дөньяга карашлары белән социаль һәм милли азатлык хәрәкәте юлбашчысы Г. Исхакыйга якын тора. Әдип үзенең гыйльми-тәнкыйди hәм публицистик эшчәнлегендә культура-тарих мәктәбе кагыйдәләренә, тарихилык һәм миллилек принципларына нигезләнә.

\section{Әдәбият}

Әдипләребез: биобиблиографик белешмәлек: 2 томда: 1 том / төз. Р. Н. Даутов, Р. Ф. Рахмани. Казан: Татар.кит.нәшр., 2009. 751 б.

Әмирханов $P$. Фатих Әмирханов турында истәлекләр. Казан: Татар.кит.нәшр., 2005. 255 б.

Бәширов $Ф . \mathrm{XX}$ йөз башы татар прозасы. Казан: Фикер, 2002. 287 б.

Бикташев $P$.И. Литературное и публицистическое наследие Ахметзяна Биктимирова (начало XX века). Автореф. на соиск. ... к.филол.н. Казань, 2007. 31 с.

Гасрый $H$. Исмәгыйль бәк Гаспринский һәм гомуми әдәби тел // Исмәгыйль бәк Гаспралы [Кереш мәкалә авт. һәм төз. Ф. Ю. Гаффарова; жаваплы мөх. Ф. М. Солтанов]. Казан: Алма-Лит, 2004. Б. 60-64 б.

Гасрый Нәжсип // Татар энциклопедиясе: 6 томда / Баш мөхәррире М. Х. Хәсәнов, жаваплы мөхәррир Г. С. Сабиржанов. Казан “ТР ФАнең Татар энциклопедиясе институты” дәүләт учреждениесе, 2010. 2 т: Г-Й. Б. 80.

Гасрый Н. Тукаев вафат // Идел. 1913. 5 апрель.

Гасрый $H$. Әдәбиятымыз мөнәкъкыйдкә мохтаж // Рецензияләрдән тәгъзияләргә: XX йөз башы татар әдәби тәнкыйте. Казан: Татар. кит.нәшр., 2008. Б. 238-241.

Гасрый Н. Яшьләр хәятыннан бер ләүхә // Ил. 1914. 2 гыйнвар (№10).

Гасрый $H$. Шимали төрки әдипләреннән Гаяз Исхакый // Әсәрләр 15 томда. 8 т.: Гаяз Исхакыйның тормышы һәм ижаты турында замандашлары (18981917) [төз., текст hәм аңлат. әзерл., кереш сүз авт. Ф. Ибраһимова]. Казан: Татар. кит.нәшр., 2001. Б. 154164. 
Гасрый H. Гыйффәт туташның шигырьләре // Ил. 1915. 5 март (№ 81); 11 март (№84).

Гасрый Н. "Хисметдин менла" (Акъегетзадә әсәре) Бер тәхлил әдәби // Аң. 1915. №9. Б. 189-194; №23-24. Б. 416-424.

Гасрый H. Әдәбият мәйданында (Мәскәүдә СССР халыкларының үзәк нәшрияты нәшере, матур басмада, 110 битлек. Иптәш Галимжан Нигьмәти әсәре) // Эшче. 1926. 20 гыйнвар (№749).

Гасрый H. Мәдрәсә мәсьәләсе (съезд дикъкатенә) // Ил. 1914. 17 июнь (№31).

Гасрый Н. “Соңгыр хан түбәсе”ндә // Аң. 1916. №2. Б. 29-33. 82.

Гасрый Н. Мәзарстанда // Аң. 1916. №5. Б. $78-$

Гасрый Н. Гыйшкым хәрабәләре (Хикәя) // Аң. 1916. №7. Б. 114-118.

Гилазов Т.Ш. Рассказ Г. Ибрагимова «Один эпизод из жизни молодежи» в литературной критике 1910 -х годов // Филология и культура. Philology and Culture. 2017. № 2(48).

Гыйлажсев Т.Ш. Әдәбият белеменең бер тармагы буларак әдәби тәнкыйть // Татар әдәбияты тарихы: сигез томда. 4 т.: ХХ йөз башы / [төз. Р .Ф. Рахмани; фән. мөх. Р .К. Ганиева]. Казан: Татар.кит.нәшр., 2016. Б. 428-453.

Гыйлажсев Т.Ш. Рецензияләрдән тәгъзияләргә: XX йөз башы татар әдәби тәнкыйте. Казан: Татар. кит.нәшр., 2008. 254 б.

Гыйлажсев Т.Ш. Нәжип Гасрыйның әдәбитәнкыйди эшчәнлегендә 3. Бурнашева (Гыйффәт туташ) шигърияте // Фәнни язмалар - 2012: КФУ ның Филология һәм сәнгать институтының фәнни язмалары / Фән. мөх. Р. Р. Жамалетдинов. Казан: Казан университеты, 2012. Б. 84-91.

Гыйлажсев Т.Ш. Нәжип Гасрый // Габдулла Тукай. Энциклопедия / [баш мөх. 3. 3. Рәмиев]. Казан: Г. Ибраһимов исем. Тел, әдәбият һәм сәнгать институты, 2016. Б.195.

Жамал Вәлиди: әдәби һәм тарихи-документаль жыентык / төз. Диләрә Абдуллина, Жәүдәт Миңнуллин. Казан: Жыен, 2010. 624 б.

Жәуһррова Ф.X Әстерхан төбәгендә татар әдәбияты (XIX-XX йөз башы). Казан: Мәгариф, 2003. 127 б.

Заһидуллина Д.Ф. Модернизм һәм ХХ йөз башы татар прозасы. Казан: Татар.кит.нәшр., 2003. 255 б.

Ибраһимов Г. Әсәрләр сигез томда. 5 т.: әдәбият hәм сәнгать турында мәкаләләр хезмәтләр (19101933) [төз., текст., иск. һәм аңл. әзерл. Хәсәнов М. Х., Гайнанов Р. Р.]. Казан: Татар.кит.нәшр., 1978. 6156.

Ибраһимов Г. Матбугат вә әдәбиятымызның барышы (еллык хисап урынына) // Әсәрләр: 15 томда. Академик басма 6 т.: әдәбият һәм сәнгать турында мәкаләләр, хезмәтләр (1910-1917) [төз., текст., иск. һәм аңл. әзерл. 3. Г. Мөхәммәтшин; фән. мөх. Т. Ш. Гыйлажев]. Казан: Татар.кит.нәшр., 2019. Б. 192-202.
Исхакый Г. Гаяз Исхакыйның татар әдәбияты турындагы доклады // Әсәрләр: 15 томда. 6 т.: Публицистика һәм әдәби тәнкыйть мәкаләләре [төз. 3 Рәмиев, Ф. Ибраһимова; текст. әзерл. Ф. Ибраһимова; аңл. һәм иск. әзерл. 3. Рәмиев; фәнни мөх. Ф. Мусин]. Казан: Татар.кит.нәшр., 2005. Б. 190-203.

Исхакый Г. Әсәрләр: 15 томда. 6 т.: Публицистика hәм әдәби тәнкыйть мәкаләләре (1902-1914) [төз. 3. Рәмиев, Ф. Ибраһимова; текст. әзерл. Ф. Ибраһимова; аңл. һәм иск. әзерл. 3. Рәмиев; фәнни мөх. Ф. Мусин]. Казан: Татар.кит.нәшр., 2005. 447 б.

Исхакый Г. Әсәрләр 15 томда. 8 т.: Гаяз Исхакыйның тормышы һәм ижаты турында замандашлары (1898-1917) [төз., текст һәм аңлат. әзерл., кереш сүз авт. Ф. Ибраһимова]. Казан: Татар. кит.нәшр., 2001. 447 б.

Исхакый Г. Әсәрләр 15 томда. 11 т.: публицистика (1934-1936) [томны төз., текст., иск. Һәм һәм аңлат. әзерл.; кереш мәкалә авт. 3. Мөхәммәтшин; фәнни мөх. 3. Рәмиев]. Казан: Татар. кит.нәшр., 2011. 399 б.

Исхакый Г. Максим Горькийга (1911, 6 гыйнвар) // Әсәрләр: 15 томда. 14 т.: хатлар һәм автобиографик язмалар (1902-1954) [томны төз., текст һәм аңл. әзерл., кереш сүз авт. Ф. Фәйзуллина]. Казан: Татар.кит.нәшр., 2013. 11 б.

Исхакый Г. Әсәрләр 15 томда. 15 т.: Гаяз Исхакыйның тормышы hәм ижаты турында истәлекләр һәм мәкаләләр (1923-1990) [томны төз., текст., иск. һәм һәм аңлат. әзерл. Г. Ханнанова, Р. Кадыйров]. Казан: Татар. кит.нәшр., 2014. 527 б.

Мәрданов Р. “Шура” журналы (1908-1917): әдәбият мәсьәләләре. Казан: Рухият, 2001. 152 б.

Мирасыбызны туплау юльнда [XX йөз башы татар балалар әдәбиятыннан] / төз. Ф. Ибраһимова. Казан: "Иман” нәшрияты, 2010. 200 б.

Мусабекова Р.Р. Сагит Сунчелей: судьба и творчество [науч. ред. Р. К. Ганиева; рец. Х. Ю. Миннегулов, Т. Ш. Гилазов]. Казань: Изд-во: “УНЫШ”, 2001. 157 с.

Мухамадиев Р.C. Проблемы формирования татарской литературной критики (1905-1917). Казань: Татар. кн. изд-во. 1982. 144 с.

Неджиб (Гасри Н.) Пробуждение русских татар и их литература // Современник. 1914. №10. С. 166177.

Галимжсан Нигъмәти: тормышы, язмышы, фәнни-методик эшчәнлеге / Т. Ш. Гыйлажев редакциясендә. Казан: “Бриг” нәшрияты, 2018. 252 б.

Рахимкулова М. Медресе "Хусаиния" в Оренбурге. 2-ое дополненное юбилейное издание, посвященное 160-летию Ахмет бая Хусаинова. Оренбург, 1997. 251 с.

Рәми И.Г., Даутов Р.Н. Әдәби сүзлек (элекке чор татар әдәбияты һәм мәдәнияте буенча кыскача белешмәлек). Казан: Татар.кит.нәшр., 2001. 399 б. 
Рәмиев 3.3. Кереш // Татар шигърияте: XX гасыр башы. Казан: Мәгариф, 2004. Б. 3-8.

Рәхмәти $C$. Гыйффәт туташ мәктүбе мөнәсәбәте илә // Йолдыз. 1915. 2 октябрь.

Сәгъди Г. Татар шагыйрьләре арасында Тукай // Безнең юл. 1923. №8 - 9. Б. 2-7.

Сәгъди Г. Бездә әдәби тәнкыйть (Үктәбернең унъеллыгына). Казан: Безнең юл. 1927. 22 б.

Сәгъи $Г$. Символизм турында. Мәскәу: Центриздат, 1932. 135 б.

Сөнгати Г. Шигырьләр һәм проза. Казан: “Меддок” нәшрияты, 2007. 184 б.

Сүнчәләй С. Әсәрләр һәм хатлар [Төз., текст., иск. һәм аңл. әзерл. 3. Рәмиев]. Казан: Татар.кит.нәшр., 2005. 367 б.

Tamap ддәбияты mapuxbl. Алты томда. 1 том / Урта гасырлар дәвере. Казан: Татар. кит. нәшр., 1984. 567б.

Tатар хикәяләре [Китапны төз., текст. әзерл. һәм кереш мәкалә авт. Д. Ф. Заһидуллина]. Казан: Мәгариф, 2007. 399 б.

Tamap иигърияте: $X X$ гасыр башы. Казан: Мәгариф, 2004. 447 б.
Тукай - ядкәрләрдә: 2 томда. 1 т. : Истәлекләр, мәкаләләр, тәгъзияләр, телеграммалар / Төзүчеләр: Р. Ф. Исламов, филология фәннәре докторы, Ж. С. Миңнуллин, тарих фәннәре кандидаты. Казан: Жыен, 2015. 968 б.

“Уйласам уй, сызльй күнлем, сызлый жсан...". Сәгыйть Рәмиевнең тормыш юлы һәм ижатына карата яңа мәгълүматлар [төз.-авт. Ч. ЗариповаЧетин; фән мөх. А. Саяпова]. Казан: “Яңалиф" нәшрият йорты, 2005. 203 б.

Фәйзи М. Әсәрләр [төз. һәм кереш мәкалә авт. Т. Ш. Гыйлажев]. Казан: Мәгариф, 2007. 295 б.

Хәсәвнех А.Ә. Ил // Татар энциклопедиясе: 6 томда / Баш мөхәррире М. Х. Хәсәнов, жаваплы мөхәррир Г. С. Сабиржанов. Казан “ТР ФАнең Татар энциклопедиясе институты” дәүләт учреждениесе, 2010. 2 т: Г-Й. 536 б.

Эпик иигърият: $Х Х$ йөз башы / төз. Ф. З. Яхин. Казан: Татарстан республикасы "Хәтер" нәшрияты (ТаРИХ), 2002. 463 б.

Яхин Ф. ХX йөз башы татар эпик шигърияте // Эпик шигърият: XX йөз башы / төз. Ф. З. Яхин. Казан: Татарстан республикасы “Хәтер" нәшрияты (ТаРИХ), 2002. Б. 5-16.

\title{
ДУХОВНОЕ НАСЛЕДИЕ Н. ГАСРИ В ЛИТЕРАТУРНОМ И КУЛЬТУРНОМ КОНТЕКСТЕ НАЧАЛА ХХ ВЕКА
}

\author{
Тагир Шамсегалиевич Гилазов, \\ Казанский федеральный университет, \\ Россия, 420008, г. Казань, ул. Кремлевская, д. 18, \\ tgilazov@bk.ru.
}

В статье систематизированы сведения о жизни и деятельности Неджиба Гасри, сыгравшего огромную роль в подъеме культурной и литературной жизни татарского народа в начале XX века. Объектом исследования послужили его статьи, посвященные истории татарской литературы, татарской критики, национальной культуры и просвещения, а также выдающимся деятелям. Общественные взгляды Н. Гасри, его эстетические ориентиры рассматриваются в контексте развития культуры и литературы начала XX века. Пристальное внимание уделяется связи духовного наследия писателя с восточными и западными литературными традициями.

Предпринята попытка создания научной биографии Н. Гасри на основе систематизации отдельных фактов. Впервые в оборот вводится ряд новых источников: статьи писателя, воспоминания о нем. Основные методы исследования: сравнительно-исторический, типологический и герменевтический с опорой на традиции и принципы культурноисторической школы.

Ключевые слова: национальное возрождение, литературные взаимосвязи, культурноисторическая школа, общественная мысль, татарская литература, литературная критика, история литературы. 